\title{
The price of knowledge
}

Nico Stehr e Marian Adolf

There are some things which cannot be purchased with wealth, and knowl-
edge is one of them. Wealth can purchase houses, lands, adherents, and
bauble honors, and a man may sit down and enjoy these things at once.
An heir to an empire may be born, he may be the legal successor to thrones,
armies, and navies; over these he may exercise dominion and be their pos-
sessor, but no man was ever born an heir to knowledge

This article addresses the apparently rather old question - as the citation from the 1851 issue of the Scientific American indicates - of how to assess and measure the value or price of knowledge. We will probe the issue from a variety of social scientific and practical perspectives. Against the background of a sociological concept of knowledge economic, political, social and juridical perspectives are discussed that may lead us to a price of knowledge.

We observe as is widely assumed that knowledge plays an ever-greater role within as well as across economies and politics and that its embodiment makes it difficult to divorce it from its carriers, if at all; and that knowledge is deeply entrenched in questions of social relations and stratification and last but not least that knowledge is subject to depreciation, decay or obsolescence ${ }^{2}$. As such, it cannot presumably

1. "Knowledge is democratic". Scientific American, 6, pp. 253-253 (26 April 1851).

2. The obsolescence of knowledge in general is an important but hardly well understood process. The impact of knowledge that becomes obsolete on the wages and earning of employees is an equally complicated issue (Rosen, 1975; Welch e Ureta, 2002). 
be captured in a straightforward manner, using either market-based tools or nonmarket evaluations especially given the persistent standoff between its individual, economic and public relevancies and benefits. A simple arithmetic of the price of knowledge fails.

\section{Point of departure}

We begin our study by pointing to some of the pitfalls of establishing exactly what theorists and practitioners are dealing with when they define the phenomenon, especially if they do so from an economist's perspective: can knowledge actually be measured, and if so, is it really knowledge that is the referent? ${ }^{3}$ Second, we deal with attempts to specify and quantify "human capital" as forms of knowledge assets by examining various approaches from within the field of economics. Third, we turn to a more sociological viewpoint in determining symbolic and knowledge capital. Discussing Pierre Bourdieu's notion of cultural capital as a form of symbolic capital, we find that it is insufficient to capture the ambivalent role knowledge plays in the processes of social stratification and empowerment. In a fourth step towards encircling attempts to put a price on knowledge, we deal with patents and other forms of intellectual property rights (IPR) that play an increasing role in today's economies. Fifth, in an attempt to find yet another proxy for evaluating the price of knowledge, the concluding chapter turns to politics and the question of taxation, in particular the public funding of education. Based on Dewey's classic question of how much knowledge a democracy requires of its citizens, we use the case of a political-legal dispute to approach the question of what knowledge is worth and how much of it we should afford. Sixth, we discuss the notion of additional knowledge, starting out from the assumption that added knowledge should be of specific value. Seventh, we examine the idea found in the economics literature that commodities are embedded knowledge. Finally, given our tentative conclusion that establishing the price of knowledge is a rather difficult task we turn to the idea of knowledge as a public good. It is an essential attribute of the concept of public goods that for those who consume them their price is negligible if not altogether absent.

3. Heather Rimes and her colleagues (2014, p. 154) argue that a market-base price of knowledge does not correspond to the "true" value of knowledge; the true value of knowledge "lies in how often and how widely is it applied - information that is not captured in market price [...] the value of knowledge derives from the intensity and the range of its use". This obviously is a helpful hint, however, it perhaps only increases the obstacles of arriving at an evaluation of knowledge, past and present and does not remove the difficulties we will describe in quantifying the price of knowledge. 
Measuring knowledge

Unlike general social labour, knowledge is impossible to
translate into - or measure in - simple abstracts units. It is
not reducible to a quantity of abstract labour of which it can
be said to be the equivalent, the outcome or the product.
André Gorz ([2003] 2010, p. 35)

The economist Herbert Simon (1999, p. 24) is much more upbeat than André Gorz about our ability to develop robust measures of knowledge. Simon emphatically stresses that all aspects of knowledge "can be (and have been) analyzed with the tools of economics. Knowledge has a price and a cost of production; there are markets for knowledge, with their supply and demand curves, and marginal rates of substitution between one form of knowledge and another". However, Simon (Idem) at least partly retracts his strong statement about the rigor with which the tools of economics can be applied by pointing out that knowledge "is simply one among the many commodities in which our economy trades, albeit one of large and rapidly growing importance. It requires special treatment only because of its special properties"4. Let us take a closer look at how these "special properties" of knowledge are dealt with from within economics.

Our examination of the mainly economics literature ${ }^{5}$ that proclaims to deal with the value or price of knowledge as an asset and the monetary return to knowledge exemplifies two assertions: First, our general contention that the terms of knowledge and information are, once again (Adolf e Stehr, 2014, p. 25f), liberally conflated (e.g. Hess e Ostrom, 2003). Gary Becker (1994a, p. 53) ${ }^{6}$, for example, notes that

4. Kenneth Boulding, like Herbert Simon, believes that knowledge can be a commodity. However, Boulding (1996, p. 2) is more reluctant in his conviction that knowledge can become a commodity. He points to a number of fundamental difficulties, which we will also discover in treating knowledge as a commodity: "It is a little hard to put [the label commodity] on it because of the difficulties of measuring the quantity of the commodity itself [...] The absence of any unit of knowledge itself, however, and perhaps the intrinsic heterogeneity of its substance, make it very difficult to think of a price of knowledge as such, and indeed has probably contributed to a certain resistance of thinking of knowledge as a commodity".

5. Samuli Leppälä (2015) summarizes the intellectual origins and the defining characteristics of the economic analysis of knowledge, employing the "standard epistemological definition" of knowledge as "justified belief". It is also noteworthy that Leppälä does not raise the issue of the price or value of knowledge in his survey of the diverse economics literature that attends to the economic role of knowledge.

6. The conceptual discussion of the so-called data-information-knowledge-wisdom hierarchy (DIKW) in the social systems literature (for example, Ackoff, 1989) explicitly offers to separate the phenomena in the form of a pyramid by referring to progressively smaller layers until one reaches the state of wisdom. 
increased knowledge raises the real income of individuals and specifies his hypothesis by saying: "information about the prices charged by different sellers would enable a person to buy from the cheapest, thereby raising his command over resources; information about the wages offered by different firms would enable him to work for the firm paying the highest (our emphasis)"

Second, we find that efforts by economists that remain and are genuinely concerned with the value of knowledge, for example in the sense of knowledge assets as "intangibles", for the most part display a strongly ambivalent idea of the value of knowledge and indicate strong doubts about the possibility of arriving at a price of knowledge. Such ambivalence contrasts of course with the massive affirmation in the literature that human resources of an organization as well as investments - at a rate close to the investment in tangibles - in research and development, software, brands, and other intangibles are the key to sustainable competitive advantages. As a result measures of the Gross National Product (GDP) that does not include all intangible investments misrepresent the actual changes in output (McGrattan, 2017). Yet, little has been done to actually capture the accountable value of such assets.

Although they are deemed as critically important for firms in the contemporary competitive economic environment, the very definition of intangibles as "unseen wealth" (Blair e Wallman, 2001; Leadbeater, 1999; Teece, 1998) ${ }^{8}$ already indicates the difficulties of devising ways of measuring the monetary value of copyrights, patents, trade secrets, brand loyalty, organizational capabilities - let alone knowledge skills (see Fulmer e Ployhart, 2014) or human capital. Carol Corrado und ihre Kollegen (2006, p. 3) verweisen aber allgemein darauf, sofern "the factors typically associated with the growth of the 'knowledge economy' assume a greater importance once intangibles are included"'.

For instance, as one "processes" data you get information and so on. Since the various steps within the pyramid are far from clear cut, in the end the proposal amounts to another conflation of the various parts that make up the DIKW pyramid.

7. On the other hand, Olivier Gossner (2010, p. 95) matter-of-factly states: “knowledge' refers to the information possessed by the agent".

8. In his discussion of "the nature of capital" more than a century ago, Thorstein Veblen ([1908] 1919, pp. 325-326) refers to part of the capital of a community as "immaterial equipment" or "intangible assets" mainly consisting of knowledge and information that "in the early days at least, $[\ldots]$ is far and away the most important and consequential category of the community's assets or equipment".

9. "We find that the inclusion of intangibles makes a significant difference in the measured pattern of economic growth: the growth rates of output and of output-per worker are found to increase at a noticeably more rapid rate when intangibles are included than under the baseline case in which intangible capital is completely ignored, and capital deepening (when expanded to include both tangibles and intangibles) becomes the unambiguously dominant source of growth in labor productivity" (Corrado, Hulten e Sichel, 2006, p. 3). 
Moreover, at least in the United States, the widely accepted accounting principles (Gaap) that govern the reporting of financial information to external sources prohibit companies from recording the value of human capital resources as assets ${ }^{10}$. Instead, human capital expenses are recorded as expenditures (Tan, 2014). Since the expenditures for and the values of human capital might not correspond, the actual price of human capital assets remains a mystery. By virtue of the difficulties inherent to determining the exact value of intangible goods and services, the validity and comparability of national indicators of the total economy, work productivity and goods distribution are uncertain and even doubtful (McCulla, Holden e Smith, 2013; Feldsein, 2017).

Such ambivalence or lack of precision (how profitable is private investment in research and development?) perhaps exemplifies and satisfies the numerous critics who are convinced that knowledge does not or should not carry a price tag and instead be part of the "public domain" (Boyle, 2003), or that it is particularly ill suited for conversion to private property and market pricing ${ }^{11}$. To begin with, therefore, we are able to assert that there is - as in the case of the social phenomenon of power - no standardized or objective approach to quantify the value of knowledge (or information).

Even assuming that one is able to specify a price, the value of knowledge will not be a constant but is likely to increase or decay (become obsolete), depending on circumstances such as the time that has passed since the initial discovery of a product, the difficulty of keeping it from other agents (the case of generic drugs)

10. But why are human capital resources not recognized by U.S. accounting standards as accountable for the purpose of financial statements? As pointed out in Sollosy, McInerney, and Braun (2016, p. 23) the U.S. Financial Accounting Standards Board "requires, among other things, that in order for an asset to be recognized for financial statement purposes, the future benefits of the resource must be under the control of the organization and that they be reliably measurable". This position has not remained without its strong critics (e.g. Fulmer e Ployhart, 2013, or Lim et al., 2010). What remains is the persistent appeal by accounting specialist's, "has not the time come to seriously consider how to best reflect the value of intangible assets in a manner that allows for the comparison of competing organizations within an industry?" (Sollosy, McInerney, and Braun (2016, p. 224). For the time being, it remains the case that "in the wake of the growth of intangible assets the ultimate measure of firm value, share prices, has become largely divorced from (historical) accounting measures" (Bryan, Rafferty e Wigan, 2017, p. 63).

11. After all, the doubt expressed toward efforts to monetarize knowledge sometimes even refers to Socrates teaching his students without demanding any monetary compensation. Socrates expressed nothing but malice for teachers who claimed to be able to generate a lofty income from their wealthy students. But what was the reason for Socrates to refuse to take money in return for knowledge? If he charged for his teaching, Socrates maintained, he would be forced to teach students he did not appreciate; in other words, he wanted to protect his liberty (see Bertram Schefold, "Die Ökonomisierung der Wissenskultur" [The economisation of the culture of knowledge]. Frankfurter Allgemeine Zeitung, April 12, 2010). 
or the assets that have to be mobilized to transmit it (Pakes e Schankerman, 1979). In our attempt to reconstruct various perspectives that aim to gain insight into the value of knowledge we will cover three cases that suggest that the value of knowledge is at issue in these discussions, decisions, or valuations of the benefits to be derived from knowledge.

The accounts that are of interest to us either attempt to gain insight into the value of knowledge by treating knowledge as a form of input, for example, in the production process, and as one of the factors of production such as human capital. Another notable approach takes the opposite perspective. In this case, knowledge becomes relevant and hence subject to attempts to value it by being treated as a form of output, for example in the sense of patents, copyright restrictions and the like.

Many of the studies and discussions that can be found in the literature that claims to deal with the price of knowledge actually are about the price of information (e.g. Rosewall, 2005). This is most notable in consumer behavior research, which examines the impact of consumers' knowledge of the price of a product/commodity on the decisions made by them in supermarkets (e.g. Olavarrieta et al., 2012; Dickson e Sawyer, 1990), the effect the product price has on consumer satisfaction (e.g. Homburg et al., 2012), the level of price knowledge that children hold (Damay, Guichard e Clauzel (2014), the impact of the price of tertiary education on university students (e.g. Junor e Usher, 2004-2005).

Most other efforts that aim to discuss the price of knowledge can be subsumed under some form of a critique of the commodification of knowledge; these efforts are mainly critical on the grounds that scientific and economic activities are embedded in distinct functional subsystems of society.

It is in this context that the nature and the influence of the work of Jean-François Lyotard on our present-day understanding of the role of knowledge as a commodity deserves to be introduced into our discussion. A prominent example of the idea that our age is characterized by a growing commodification of knowledge may be found in Jean-François Lyotard's ([1979], p. 1) La condition postmoderne. Lyotard offers the working hypothesis that the status of knowledge has beginning on the 1950 s been altered "as societies enter what is known as the postindustrial age and cultures enter what is known as the postmodern age". Lyotard refers in this context to the standard text by Daniel Bell or Alain Touraine about the emergence of postindustrial economies. Lyotard ([1979], p. 4) offers the following observations about the fate of knowledge in the modern age:

We may $[. .$.$] expect a thorough exteriorisation of knowledge with respect to the "knower",$ at whatever point he or she may occupy in the knowledge process. The old principle that 
the acquisition of knowledge is indissociable from the training (Bildung) of minds, or even of individuals, is becoming obsolete and will become ever more so. The relationships of the suppliers and users of knowledge to the knowledge they supply and use is now tending, and will increasingly tend, to assume the form already taken by the relationship of commodity producers and consumers to the commodities they produce and consume - that is, the form of value. Knowledge is and will be produced in order to be sold, it is and will be consumed in order to be valorised in a new production: in both cases, the goal is exchange.

Knowledge looses its early dominant "use-value" and its value is reduced to its "exchange-value", that is, the commercialization of knowledge. The point of departure in discussions about the commodification of knowledge, then, tends to be the observation that a growing volume of scientific activities especially in the field of genetics and biochemistry is no longer curiosity-driven but carried out in the laboratories of private corporations; as a result, knowledge increasingly takes on the characteristics of a commodity. The economization of science is criticized (e.g. Balzer, 2003), for example, in the case of efforts to patent genes (see Matthijs, 2004; Resnik, 2004). Lyotard does not, however, offer any hint of the effect of the commodification of knowledge on the price of knowledge except perhaps in the most general sense that market forces will be responsible in setting prices.

Both of these approaches confirm the sensitivity of claims that knowledge comes with a price tag. Knowledge is simply a much too "valuable", "special" and uniquely human or "largely unobservable" 12 resource for it to be measured in any strictly monetary sense. Is the aim therefore to price knowledge an effort to "price the priceless"? After all, knowledge in many ways resembles wisdom, insight, good judgment or "nature" (Fourcade, 2011) that are not at home in the market place ${ }^{13}$. Hence the often-repeated assertion that what cannot be counted or quantified is not necessarily without value. We will return to this observation in our discussion of patents.

Still, according to some of the most influential international organizations, the World Bank (e.g. 2011) and the United Nations (e.g. UNU-IHDP e Unep, 2014), it is "human capital" that is the most significant component of human wealth for most countries in the modern world. Economic growth requires capable workers. In other words, there is widespread agreement among social scientists that knowledge is the core determinant of economic growth in modern societies. For example, Claudia Goldin and Lawrence Katz (2008) show how human capital has been the defining

12. Dominique Forey (2006, p. 9), for example, emphasizes that "knowledge is largely unobservable" and "most phenomena relating to knowledge are largely unmeasurable".

13. "Where is the wisdom we have lost in knowledge? Where is the knowledge we have lost in information?" T.S. Eliot, Choruses from "The Rock", 1934, I. 
factor for the economic identity of the industrialized world of the $20^{\text {th }}$ century (also Acemoglu e Autor, 2012) ${ }^{14}$. However, there also is widespread disagreement about the exact terms of analysis. The expressions "human capital", "skills", "information", "capacities" and "knowledge" that can be applied to all occupations, jobs, tasks and sectors of the economy are widely conflated in many of the studies. It is in general often also unclear how exactly human capital attributes are related to job performance and hence to rewards that might accrue to different values that the human capital of individuals constitutes.

Since human capital is seen to be virtually identical with the knowledge acquired and commanded by individuals, it would appear to be self-evident that the value offered in terms of human capital should constitute a road to an assessment of the value of knowledge. However, this is not the case, as we will show in the next section.

\section{Human capital}

Among the theoretical approaches and concepts that might be regarded as a proxy for the price of knowledge, cultural capital and buman capital theories stand out. For example, efforts are made by economists to estimate the value of the "most valuable asset most people own [which] is their human capital" (Haggett e Kaplan, 2015, p. 1); by the same token, corporations are quick to endorse the slogan "our employees are our best and most important asset". For corporations and the economy information about the value of human capital becomes a resource for financial reporting, fiscal management and managerial and political decision-making.

The struggle among the relative weights of those shares of collective income that are generated in the economy by different forms of capital has significant repercussions for the formation of inequality in a society. Thomas Piketty ([2013] 2014, p. 21) for example notes, "the progress of technological rationality is supposed to lead automatically to the triumph of human capital over financial capital and real estate, capable managers over fat stockholders, and skill over nepotism". But, as he adds a cautionary remark, "inequalities would thus become more meritocratic and less static (though not necessarily smaller): economic rationality would then

14. Daron Acemoglu and David Autor (2012, p. 427) summarize the historical and econometric evidence of Goldin and Katz's (2008) study: "Human capital is a central determinant of economic growth, both in general and in the specific case of economic growth in the United States during the twentieth century". In addition, the study demonstrates according to their reviewers that the steady accumulation of human capital is a major equalizing force in the labor market of the United States. It follows that rising inequality is a function of a slowing rate of accumulation of human capital in light of a growing demand for skilled-based occupations (Acemoglu e Autor, 2012, p. 456). 
in some sense automatically give rise to democratic rationality" (Piketty, [2013] 2014, p. 21).

In the course of the emergence of the knowledge-based economy, the linkage and the dependence of economic capital on cultural capital - and as we would specify, knowledge capacities - is significantly enhanced. Strata and individuals who are good at mobilizing knowledge capacities, for example, exploiting discretionary opportunities or the ability to generate new and persuasive ideas, are more likely to accumulate and defend financial gains within the frame of the knowledge economy (see Stehr, 2016, pp. 101-108).

The notion of human capital has been developed and deployed primarily within economic discourse (Schultz, 1961; Becker, 1964; Tan, 2014) and, more specifically, the economics of education ${ }^{15}$. A variant of human capital theory, or its development in terms of incorporating empirical indicators of skills (for example, cognitive skills such as math, science, and literacy skills across countries), is what Eric Hanushek and Ludger Woessman (2015, p. 16) call knowledge capital theory. In any case, in human capital theory education plays a crucial role.

As Gary S. Becker (1994b, p. 16) in a subsequent revisit of human capital theory therefore summarizes, "expenditures on education, training, medical care, etc., are investments in capital. However, these produce human, not physical or financial, capital because you cannot separate a person from his or her knowledge, skills, health, or values the way it is possible to move financial and physical assets while the owner stays put”. My human capital, in more extensive sense, as Michel Feher ([2007] 2009, p. 26) describes it succinctly "is me, as a set of skills and capabilities that is modified by all that affects me and all that I affect [...] [Human capital] now refers to all that is produced by the skill ser that defines me. Such that everything that I earn - be it salary, returns on investment, booty, or favors I may have incurred - can be understood as the return on the human capital that constitutes me". Thus, it is not only the formal education that counts as input to a person's human capital but social influences too, such as that of the family.

15. An early critique of treating persons as human capital, thus constituting individuals not based on moral or ethical factors but on the logic of economic discourse, may be found in Shaffer (1961). Harry Shaffer objects that the term "investment" is not really applicable to the issue of human capital; "investment" in individual employees should not be used as a basis for policy formation. A fundamental criticism of the human capital theory is therefore also prompted by the (implicit?) idea that a more comprehensive school education is associated with productivity gains and that a higher income of these groups is seen as a function of these productive gains (e. g., Gouldner, 1979, p. 108). Randall Collins (1971) refers, as Gouldner (1979, p. 108) emphasizes that "the main activity of schools [...] is to teach status cultures, this socializing persons to gain admission to status groups and their privileges" (see also Stehr, 2000). 
It is within the context of human capital theory that the value of knowledge, skills and capabilities of active economic agents and their costs becomes a relevant consideration. Not all the returns to human capital investment are necessarily monetary in nature; "a person's appreciation of literature over much of is or her lifetime" may also be a return to investment (Schulz, 1962, p. 7). But as the typical usage of the human capital theory in economics indicates what counts above all is the income generated by one's human capital assets. In the world of symbolic economy valued income includes income from or the appreciation of financial products.

If however we extend the consideration of the price of labor both comparatively across different societies or regions within societies (Teal, 2011, p. S8), then the price of labor is much more determined by where the person lives rather than the volume of human capital (held constant across nations or regions) an individual commands; and when we enlarge the time frame historically, then when a person lived is much more significant for the price of labor than her human capital (held constant over time). History and geography matter. And as Francis Teal (Idem) therefore concludes, "The central fact about the price of labour is that its price is much more closely correlated with where the person lives than with what they know".

Just as physical capital is created by changes in the means of production brought about by new instruments and artifacts that facilitate production, human capital rests on the transformation of individuals who impart skills and capacities ${ }^{16}$ that allow them to contribute to productive processes ${ }^{17}$. In contrast to other forms of capital, human capital is embodied in its owner. Human capital is related to a worker's earning capacity in the labor market. In its most simplified variety, human capital theory - with its strong influence on neo-liberal economic theory - expects income differences to be a strict reflection of acquired skill differentials of occupations. You earn what you deserve, as David Ricardo had already argued. The evaluation of human capital proceeds by analogy with the valuation of fixed capital.

The acquisition of skills is a form of durable investment rather than consumption. The acquisition of human capital is fostered by the desire of the individual agent

16. An exceptional, deviant definition of human capital that extends to so-called innate abilities of individual agents is rarely found in economic discourse; but see Laroche and Mérette (1999, p. 88) for such a conception.

17. Human capital theory resonates strongly with post-war mainstream sociological theories of social stratification, for example, Talcott Parsons' ([1949] 1954, p. 327) theory of social stratification: "the status of the individual must be determined on grounds essentially peculiar to himself, notably his own personal qualities, technical competence, and his own decisions about his occupational career and with respect to which he is identified with any solidary group... [...] It is nevertheless fundamental that status and role allocation and the processes of mobility from status to status are in terms of the individual as a unit and not of solidary groups, like kinship groups, castes village communities etc.". 
to maximize utilities, a future-oriented perspective, constant rational conduct and stable preferences. The choices of the individual are constrained by market forces, time, income, and available opportunities (Becker, 1993) and thus depend on the conduct or judgment of others.

Skills can be acquired by attending school and job training. Learning and training of course also happens outside formal educational institutions, especially on the job (Becker, 1994b, p. 20). In research on human capital, the number of years of schooling and job training is typically taken as a proxy for differential skills (for an example with historical data, see de Pleijt, 2016). Existing estimates of the rate of return rely almost exclusively on school attainment as a substitute for various skills relevant to occupational achievement (typically focusing on early career workers) rather than on any direct measures of cognitive skills and capacities over the full occupational history of workers such as ongoing learning (see Hanushek, Schwerdt e Wiederhold, 2015). A cautionary note would therefore refer, as Peter Cappelli (2014, p. 31) stresses: "Using education as a proxy for the 'skill' that employers want should be interpreted with caution as well given that the extensive literature in job analysis shows that the knowledge, skills, and abilities that are used in jobs have at best only a partial overlap with what is taught in typical college courses".

These estimates indirectly indicate the price of knowledge in the form of skills that make the employee more productive. Louis Garicano and Esteban Rossi-Hansberg (2015, p. 5) make the point that it is not merely an estimate of the value of educational achievement that allows for a calculation of the value of human capital: "Perhaps the best measure of the marketable knowledge and skills of an agent is his or her wage". In the end, the close correlation between wages and education ensures that every analysis of human capital value arrives at the same conclusion independent of its point of departure. Educational attainment as such is of course not irrelevant to occupational success; and, as internationally comparative studies have indicated, both the quality and quantity of education contribute to country differences in income and economic growth (e.g. Schoellman, 2012).

An initial reduction in consumption or abandonment of other investment opportunities by economically rationally acting and motivated actors should pay off at a later time in the form of higher levels of income. Indeed, it is one of the governing assumptions in economic discourse on human capital that differential earnings are in fact related to the individual (atomistic) capital at hand in an unambiguous fashion and based on motives that are constant across time and space (for a competing, sociological perspective see Fevre, Rees e Gorard, 1999; Hilmer e Hilmer, 2012).

It is on the basis of these assumptions that estimates of the price of skills (Mincer, 1974) and the rate of returns on investments into human capital are calculated (e.g. 
Blaug, [1965] 1968). What proportions of the returns to skills will be appropriated by the individual who has invested in these skills is indeed a contentious matter. The corporation expects benefits (e.g. Barney, 1991; Becker e Gerhart, 1996) and may even appropriate most of the returns to the skills of the individual worker.

As long as labor market competition is free especially from extraneous constraints, and competition therefore approaches perfect competition, human capital theory assumes that income differentials among individuals directly reflect differential investments in the acquisition of the relevant skills. Human capital theory, then, amounts to a theoretical perspective that explains equality rather than inequality. "Unearned income" can only be generated by competitive distortions (see Atkinson, 1983, p. 104; Berger, 2004, pp. 367-368). From a macro-perspective an increasing supply of human capital to the economy will reduce - assuming a demand for human capital that is lower than the supply - the skill premium or the value commanded by human capital (Acemoglu e Autor, 2012, p. 427).

Human capital is not homogeneous; for example, it is possible to distinguish between general human capital that is mobile, and specific context-sensitive human capital that is not mobile across boundaries. It is often argued that change in the kinds of skills in demand on the labor market is the result of changes in technology. Only the individual who made the investment in the first place can, under most circumstances, appropriate returns on human capital. Human capital is embodied capital. It cannot be separated from the individual, but the value of the investment depends also on the assessments made by other agents (see van Doorn, 2014) or on the network of social relations this individual is able to mobilize. The stock of human capital cannot be directly traded and transferred unless one trades and transfers the individual person. Human capital theory is silent on the influence of collective factors such as, for example, the societal reputation of educational degrees that affect the successful acquisition of human capital or, correspondingly, the failure to do so. It is equally opaque on the question of the depreciation of human capital and therefore on how the earning streams may decline or, for that matter, continue to grow over time $^{18}$. Unlike the impact on capital invested in the plants and the equipment of a corporation, the impact of recessionary economic times, for example, on the value

18. Based on considerations of this kind, Michel Feher ([2007] 2009, p. 27) argues that "an investor in his or her human capital is concerned less with maximizing the returns on his or her investments - whether monetary or psychic - than with appreciating, that is, increasing the stock value of, the capital to which he or she is identified. In other words, insofar as our condition is that of human capital in a neoliberal environment, our main purpose is not so much to profit from our accumulated potential as to constantly value or appreciate ourselves - or at least prevent our own depreciation". 
of human capital (does it depreciate or even increase in value?) is an unexplored question (see Stiglitz, 2015, pp. 6-10) ${ }^{19}$.

By the same token, human capital theory tends to be quiet on the impact of socio-structural features of society and the nature of the economic system that may enhance or reduce payoffs in return for the investments made by the individual. Finally, human capital theory is silent "on what factors determine the skills that are demanded [...]. [E]mpirical analysis of the return to education is not directly informative about what skills workers use on the job, why these skills are required, and how these skill requirements have changed over time" (Autor e Handel, 2009, p. 1).

Human capital theories as well as efforts to apply them empirically remain hamstringed by the superficial stylized notion of how human capital manifests itself in social reality. Mark Granovetters (1985, p. 486; also Williamson, 1975, pp. 255258) general criticism of those economists who recognize the importance of social relationships also applies to the typical exposition of theory and empirical study of human capital: "The interpersonal ties described in their arguments are extremely stylized, average, 'typical' - devoid of specific content, history, or structural location".

The empirical representation of human capital is for the most part seen, as we have pointed out, to reflect the number of years of schooling; schooling being taken to represent a homogeneous variable and a valid indication of the differential skills and knowledge of the individual. Dajun Lin and his co-authors follow the convention of quantifying human capital by relating "cognitive performance" as measured by the end of secondary schooling in relation to labor market outcomes of twenty through fifty years old individuals. The labor market outcomes taken into consideration in relation to cognitive performance are annual labor incomes and work hours and hourly wage rates as well as a measure of total (discounted) lifetime labor income. The cognitive performance was measured from scores of the Armed Forces Qualification Test (AFQT): "AFQT scores are calculated using information from four of the ten Armed Services Vocation Aptitude Battery (Asvab) of tests - word knowledge, paragraph comprehension, math knowledge and arithmetic reasoning"

19. See also the discussion of the creative class typology of occuations by Gabe, Florida and Mellender (2013, p. 39) who assert that "in contrast to the educational-based human capital measure, the Creative Class occupational typology takes into account what people actually do (and related skill requirements) in their current jobs, rather than the amount of schooling they have completed". The empirical evidence the authors (Gabe, Florida e Mellender, 2013, p. 51) consulted for the us labor market between 2006-2011 indicates that "that having a Creative Class occupation lowers an individual's probability of being unemployed - in fact, the effect is larger than the marginal effect associated with having a four-year college degree (compared to someone with only a high school diploma) - and that the impact of having a creative occupation became more beneficial in the two years following the recession". 
(Lin, Lutter e Ruhm, 2016, p. 14) ${ }^{20}$. The analysis shows that "cognitive performance is positively associated with future labor market outcomes at all ages" (Idem, 2016, pp. 4, 24); moreover the "cognitive skill effect on income is universally larger for women than men, although the differences are not always statistically significant, with particularly pronounced gaps at young ages". The effect of early life human capital investment of cognitive performance (exempting non-cognitive abilities in reaching adult outcomes) increases with age. The relationship continues to be observable after controlling for non-cognitive characteristics. The reported relations between an early-life cognitive achievement test and income could be the outcome of a number of varied intervening factors and social processes including for example the social status of the family of the individual subjects.

The Becker-Tomes (1986) model of the intergenerational transmission of human capital recognizes the impact of previous generations on the individual's acquisition of human capital. Specifically, the Becker-Tomes model proposes that the level of human capital and the abilities of parents matter for the human capital of their children when credit constraints limit the parents' ability to invest in the human capital formation of their offspring. Whether or not the rational understanding of economic constraints or opportunities by parents, let alone their educational attainment, plays a role in the intergenerational transmission of human capital is a contested issue. A similar open question is the influence of grandparents on the transmission of human capital (see Lindahl, Palme, Sandgren-Massih e Sjögren, 2014). In the final analysis, however, human capital theory tends to treat the complex dimension of cognitive capacities and skills and the intergenerational transmission of these abilities as a black box.

Eric Hanushek and his colleagues (2015) have tried to partly fill this gap by providing information about the returns to cognitive skills across the entire labor force, using data from the Programme for the International Assessment of Adult Competencies (Piaac) for 23 countries. How do earnings (expressed in pre-tax and pre-transfer wages) of full time workers between 35 and 54 years of age differ depending on a direct measure of cognitive skills $?^{21}$ The results obtained in this analysis of

20. The dollar amounts reported for the impact of cognitive performance of life time income are as follows: "A 0.1 standard deviation increase in $\mathrm{AFQT}$ is associated with a rise of 2.15 percent, or $\$ 11,846$, in lifetime income through 65 for the average NLSY79 respondent, which translates into an increase of $\$ 19,545$ for an infant born in 2014 . The predicted effect is somewhat larger in absolute terms for men than women ( $\$ 20,724$ versus $\$ 16,778$ for 2014 births) but since women earn less than men, the percentage growth is substantially larger for females (2.62 percent versus 1.71 percent)".

21. Piaac attempted to measure the cognitive and workplace skills that are needed to advance both on the job and in society. In 23 countries, a representative sample of adults was interviewed. Information about three fields of cognitive skills was collected: literacy, numeracy and problem solving in a high- 
the Piaac data focus on numeracy skills, that is, the "ability to access, use, interpret, and communicate mathematical information and ideas in order to engage in and manage the mathematical demands of a range of situations in adult life", which the authors of the study considered comparable across countries.

The results "consistently indicate that better skills are significantly related to higher labor-market earnings, [...] a one-standard-deviation increase in numeracy skills is associated with an average increase in hourly wages of 17.8 percent across the 23 countries" (Hanushek, Schwerdt e Wiederhold, 2015, p. 108). The returns to skills, measured across numeracy, literacy and problem-solving domains, however, vary significantly from country to country. Returns to skills are twice as high in the United States as in the Scandinavian countries.

\section{Symbolic and knowledge capital}

In contrast and in addition, the theory of cultural, symbolic and social capital mainly explicated by Pierre Bourdieu within sociological discourse, and the idea of knowledge capital proposed by André Gorz ([2003] 2010, pp. 1-2) begin to open up the black box of symbolic capital and alert us to the existence of immaterial forms of capital and the complex ways of its context-sensitive acquisition. Pierre Bourdieu ([1983] 1986, p. 241; see also Michels, [1908] 1987, pp. 140-141) explicates his insights into the role of immaterial capital that can be translated into economic capital (that is "immediately and directly convertible into money") with the economic perspective, particularly a Marxist approach, very much in mind.

Bourdieu ([1983] 1986, p. 243) first encountered the usefulness of the notion "cultural capital" in social inequality research. This origin of Bourdieu's theory of the reproduction of privilege has a considerable impact on the ways in which the notion of cultural capital designed to enlarge the orthodox concept of class is strategically deployed in discourse. Bourdieu's research was designed to explain the unequal academic achievement of children from different social classes in France; unequal academic achievement, or the "specific profits" (failures) students are able acquire in the academic market, are related to the existing stratified distribution of cultural capital among social classes and the unequal chances of acquiring such capital at home (Bourdieu e Passeron, [1964] 1979). Cultural capital is added to existing cultural capital stocks, thereby reproducing the structure of the distribu-

technology environment. Literacy, for example, was defined as the "ability to understand, evaluate, use and engage with written texts to participate in society, to achieve one's goals, and to develop one's knowledge and potential" (Hanushek, Schwerdt, e Wiederhold, 2015, p. 108). 
tion of cultural capital between social classes (Bourdieu, [1971] 1973, p. 73). It can therefore be argued that the benefits that derive from the unequal distribution of cultural capital represent a form of unearned income. Given its intellectual origins, Bourdieu's theory of cultural capital is fundamentally about societal power and domination. As a result, Bourdieu's main concern is with the role this capital plays in the reproduction of social hierarchies.

Although the educational system is of course not the only social site where cultural capital may be acquired, education not only fulfills a role in converting academic into social hierarchies but has a function also in the legitimation and perpetuation of the social status quo. The pretensions of "merit", "gifts", skills, equal opportunities and democratic selection that appear to put the chances of acquiring cultural capital in the educational systems onto an equal footing are weakened by virtue of the fact that "the ruling classes have at their disposal (to begin with) a much larger cultural capital than the other classes" (Bourdieu, [1971] 1973, p. 85). The modern educational system canonizes privilege by ignoring it.

Bourdieu distinguishes between different forms of cultural capital: its embodied or symbolic form as internalized culture, its objectified form in material objects and media, and its institutionalized form (for example, as academic certificates) ${ }^{22}$. These distinctions signal the ways in which cultural capital is stored and passed on by way of becoming an integral habitus of the individual. Bourdieu identifies two additional forms of capital, economic capital and social capital. Social capital refers to the gains individuals may derive from their network of social relations (also Coleman, 1988) ${ }^{23}$. The various forms of capital correlate highly with each other and form

22. It might be pointed out that Bourdieu's discussion of cultural capital resonates strongly with Georg Simmel's observations ([1907] 1978, pp. 439-440) in The philosophy of money about the role of the "intellect" in modern society. Simmel notes "the apparent equality with which educational materials are available to everyone interested in them is, in reality, a sheer mockery. The same is true for other freedoms accorded by liberal doctrines which, though they certainly do not hamper the individual from gaining goods of any kind, do however disregard the fact that only those already privileged in some way or another have the possibility of acquiring them. For just as the substance of education - in spite of, or because of its general availability - can ultimately be acquired only through individual activity, so it gives rise to the most intangible and thus the most unassailable aristocracy, to a distinction between high and low which can be abolished neither (as can socio-economic differences) by a decree or a revolution, nor by the good will of those concerned [...]. There is no advantage that appears to those in inferior positions to be so despised, and before which they feel so deprived and helpless, as the advantage of education".

23. For James Coleman (1988, pp. 100-101) social capital "comes about through changes in the relations among persons that facilitate action [...]. Just as physical capital and human capital facilitate productive activity, social capital does as well. For example, a group within which there is extensive trustworthiness and extensive trust is able to accomplish much more than a comparable group without that trustworthiness and trust". Coleman's definition of social capital indicates that is impossible to quantify the value of individual social capital. 
what could be called capital "repertoires". One form of capital "comes to be added, in most cases" to other forms of capital, for example, cultural to economic capital (Bourdieu, [1971] 1973, p. 99).

We will focus on Bourdieu's concept of cultural capital (or informational capital) since it resonates, at least on the surface, more closely with our concept of knowledge, that is, knowledge as a capacity to act ${ }^{24}$. In Bourdieu's understanding, cultural capital as a form of symbolic capital is much broader but also less tangible than the concept of human capital favored by economic discourse ${ }^{25}$. In contrast, the idea of knowledge capital as developed by André Gorz ${ }^{26}$ is a form of knowledge that is not acquired in settings of formal education but in everyday life and belongs to everyday culture. As a matter of fact, the notion of knowledge capital resonates closely with the concepts of knowledge skills that we have explicated elsewhere (Stehr, 2016).

As we have seen, modern economic human capital theory relates deliberate and measurable educational investments (and achievements) in the acquisition of useful skills and knowledge to the monetary gains or losses they generate, and therefore to the value of knowledge. As one of the originators of the idea of human capital, Theodore W. Schultz (1961), contends that skills and knowledge have grown in Western societies at a much faster rate than nonhuman capital. Schultz suggests that investment in human capital embodied in human beings has driven much of the growth in the real wages of income-earning individuals in recent decades, as well as economic growth in general (Benhabib e Spiegel, 1994) 27.

24. See Adolf and Stehr (2014) and Stehr and Adolf (2015) for an extensive discussion of the concept of knowledge as a "capacity to act".

25. More specifically, symbolic capital represents a social process and accomplishment; symbolic capital refers to intellectual or cognitive capacities; symbolic capital "is made [...] by those who are submitted to it but if, and only if, the objective structure of its distribution is at the basis of the cognitive structures that they bring into play in order to produce it - as, for example, with such structuring oppositions as masculine/feminine, young/old, noble/common, rich/poor, white/black. etc." (Bourdieu, 1999, p. 336).

26. André Gorz's ([2003] 2004, p. 9) notion of knowledge capital or, rather, the knowledge that counts in the modern knowledge economy can be found in his introduction to the German edition of his book on The immaterial: knowledge, value and capital ([2003] 2010). However, Gorz's idea is closely linked to economics: what is required in all branches of the economy is knowledge and, due to the growing "informatization", knowledge not in the forms that are acquired in formal education but, rather, "non-formalized forms of knowledge [...]. What is required is empirical knowledge, judgment, coordination, self-organization and communication ability, i.e. forms of living knowledge that can be acquired in everyday social dealings and is part of popular culture". It is only on the basis of his specification of the relevant knowledge forms that a proximity to the concept of knowledge capability becomes visible.

27. Mara Squicciarini and Nico Vogtlaender (2014) demonstrate that human capital (in the sense of worker skills) is a strong predictor for economic development not only today but was so already at the beginning of the industrial revolution (also Mokyr, 2005). 
In strong contrast, cultural capital theory does not proceed from the assumption of a kind of tabula rasa that allows all individuals to enter and participate in the competitive market where human capital is allocated and where success or failure is most affected by unequal natural aptitudes. Cultural capital theory not only acknowledges the preexisting unequal access to the distributional channels for its accumulation but also the different ways in which the "market" promotes the chances of particular players from the very beginning. In a largely undifferentiated society or community, of course, culture does not function as a vehicle for the emergence of differential cultural capital. As the societal division of labor increases, however, the social conditions of the transmission of cultural capital tend to be much more disguised than those that govern the transmission of economic capital. The portion of individual lives that can be afforded for the acquisition of cultural capital is highly significant. Cultural capital yields benefits of distinction for its owner.

Even though the analysis of the acquisition and transmission of cultural capital is situated within what Bourdieu calls "social fields" (see Wacquant, 1989, p. 39), one of the most evident drawbacks of Bourdieu's explication of cultural capital theory is, first, its strong individualistic bias, that is, the extent to which he stresses the fusion of cultural capital with the personality of its individual owner. Cultural capital is not a homogeneous phenomenon. Not all cultural capital is equal. Cultural capital is fragile. Fashion and the demand for novelty change the value of specific forms of cultural capital.

With Bourdieu, the emphasis remains for the most part on cultural capital as an inherent attribute of the individual carrier. Cultural capital in the form of educational credentials, for example, declines and dies with its carrier since it has the same biological limits as its carrier. Bourdieu's individualistic conception of cultural capital appears to be linked to his determination not to dispossess cultural capital theory of the ability to calculate and attribute investment gains that derive from cultural capital. And such returns of investment are seen to accrue primarily to the investor. In this sense, cultural capital theory continues to resonate with human capital theory. It contains crucial residues of the economic discourse ${ }^{28}$. Frequent references to the marketplace, to supply and demand, to costs, investments and profits would be examples of such a conflation of perspectives. It is important to recognize

28. In Bourdieu's defense one has to recognize that however strongly the quantity of capital acquired may depend on, for example, the stock of capital already accumulated in the family of an individual, its actual acquisition is - as Simmel ([1907] 1989, p. 439) already observed - ultimately an individual activity. Moreover, Bourdieu (Wacquant, 1989, pp. 41-42) defends himself against the charge of a narrow "economism"; his choice of the term "capital", for example, does not mean that he also adopts the narrow, economic conception of interests manifest in a single universal interest. 
that cultural capital is embodied in collective processes and structures; hence the benefits typically do not accrue only to those who have invested resources, which raises the free-rider issue. The production as well as consumption of such capital is not charged to the individual. It is borne by the collectivity. At one extreme, such capital can even be seen to be entirely free in that its use by certain individuals does not diminish its utility for or availability to others. Cultural capital is human-made capital and as such subject to limits and dynamics applicable to all human products and creations, especially in modern societies.

Second, and as we have emphasized already, Bourdieu discovers and utilizes the concept of cultural capital in the context of social inequality research. The concept derives much of its coherence and its critical tone from this context, a context in which the persistence of distinction, of processes of inclusion and exclusion, domination and subordination play a decisive role. Bourdieu thereby retains a strong reference to the objective and inescapable presence and constraint of the social, economic and political presence of social class in modern society ${ }^{29}$. Cultural capital, in the end, is merely derivative and closely mirrors the objective realities of class. As John R. Hall (1992, p. 257) therefore observes, "the dazzling variety and endless differences of culture obtain surprising coherence when we look at them through the lens of social stratification".

Cultural capital becomes a peculiar entity that is apparently acquired and transmitted (reproduced) almost mechanically though in a selective fashion with great ease, considerable precision and success. The risks of failure appear to be at a minimum while the possibility of a perpetuation of the cultural and socio-structural patterns is at a maximum. Whether such a description conforms to reality is questionable, as is the idea that there is a close correspondence between particular manifestations of culture and class membership (see Halle, 1992, pp. 134-135). Culture is much more fluid and leaves "much opportunity for choice and variation" (DiMaggio, 1997, p. 265).

Access, at least today, is much more open than a theory of cultural capital that stresses the stratification of power and domination in society would suggest. Pierre Bourdieu's distinction and the openness for change, resistance and innovation accorded to the capacities of individuals and groups are limited (Garnham e Williams, 1986, p. 129). But cultural frames and meaning production as well as re-production

29. Sympathetic critics of Bourdieu's capital theory have pointed to other attributes of his approach as problematic; for example, reference is made to the holistic presupposition as a general theoretical assumption. Bourdieu tends to postulate cultural capital as a generalized medium of accumulation and distinction that is not suited for the analysis of a society with multiple cleavages and divisions (see Lamont e Lareau, 1988; Halle, 1992). 
in an immense and creative variety of ways is the hallmark of the work that cultural capital conceived of in a less mechanical fashion may well accomplish for individuals and collectivities. It must also be asked if the relevance of class divisions is not undermined or even eliminated by virtue of the transformation of economic realities. In such a society, distinctions and advantages that are linked to cultural processes are not merely derivative and subordinate but foundational (Stehr, 2002). The extent to which the educational system in modern societies actually fails to faithfully reproduce the existing system of social inequality (Boudon, 1974) is testimony not only to the dynamic character of modern society but also to profound changes in inequality regimes in which knowledge and knowledge skills play a more significant and independent role (see Stehr, 1999; Stehr, 2015).

Third, although the notion of human cultural capital is not employed in a fully ahistoric manner, it is for the most part devoid of historical specificity, lacks linkage to various major societal formations such as industrial society, the state or science and is at times also used not unlike the notion of years of education in human capital theory (e.g. Bourdieu, [1984] 1988, pp. 230-232). Bourdieu does not explore the socio-historical conditions under which different strategies and regimes of inequality formation become possible. In principle it would seem that the idea of different forms of capital was universally applicable although the extent and the ease of their convertibility - for example the extent to which parental labor at home can be translated into status attainment for their children - varies within historical contexts (see Calhoun, 1995, pp. 139-141).

New "structures of consciousness" (to use a term coined by Benjamin Nelson, 1973) cannot be captured by Bourdieu's theory of cultural capital. In many ways, the structure of consciousness of knowledge societies is, of course, not novel. It resonates with the consciousness of modernity that dates - although this, too, is a highly contested issue - at least from the more immediate socio-historical origins of the French Revolution. In other respects, the conscience collective in knowledge societies is at variance with the belief systems and mental sets that are usually identified as uniquely modern and therefore warrants to be called a new structure of consciousness. In any event, the notion of cultural capital seems ill-designed to capture such transformations. Given its close reliance on the assertion that cultural capital is about power and domination, it cannot capture the opposite phenomenon, namely the extent to which knowledge is strategically deployed to soften and undermine authority, power and domination. 
Patents represent a legal grant (a category in law) by (typically) a state or bundle of states such as the European Patent Office (EPO) or a series of corresponding patents (Triadic Family of patents at the EPO, the United States Patent and Trademark Office (Uspto and the Japan Patent Office). A simple definition of a patent would be that the inventor is granted property rights for a specified time (seventeen years in the United States) and space in analogy to the general legal rules governing property in general. The owner of the invention acquires a legal title that prevents others from making, using, or selling the invention while granting the owner the right to sell her "intangible" asset for a price. A patent - often acquired in a lengthy administrative process involving highly specialized experts - grants the owner the right to practice the invention described in the patent. Thus, patents convert knowledge into private property $^{31}$ and knowledge becomes scarce in a legal sense. It is the owner of the patent who has to insure that the patent is not misused. Under the conditions of globalization such a control can be most difficult. A patent may come with strict or weaker restrictions of its use by other actors. The policy challenge is to find the right mix (Forey, 2000, pp. 76-77).

Since the 1980s, policies with regard to the legal protection of intellectual property (patents, trademarks, copyrights) have changed radically, and litigation about patent infringements has risen (for example, the patent struggle between Apple and Samsung about the design of the smart phone) $)^{32}$. With the World Trade Organization's (wTO) Agreement on Trade-Related Aspects of Intellectual Property (Trips), stringent und unprecedented obligations have been enacted for all members of the WTO with respect to their national intellectual property policies. In order to take part in international trade and access foreign markets, every member country has

30. An informative discussion and description of intellectual property concepts and procedures including a brief reference to patent law systems may be found in Knight (2013, pp. 1-48). A history of the idea of intellectual property rights may be found in Long (1991) and Hesse (2002).

31. On the sociological definition of private property rights and its implicit utilization ban, see Heinrich Popitz, (1986, pp. 111-112). For a discussion of the various advantages identified in the literature on patents see Budish, Roin and Williams (2016). Of course patents also involve costs. "The average U.S. patent costs an estimated $\$ 20,000$ to obtain and thousands more to keep from expiring before its term, which is 20 years from the application date" (Farre-Mensa, Hegde e Ljungqvist, 2017).

32. As the Guardian (February 12, 2013) reported, "the agricultural giant Monsanto has sued hundreds of small farmers in the United States in recent years in attempts to protect its patent rights on genetically engineered seeds that it produces and sells"; a report by the Center for Food Safety and the Save Our Seeds campaigning groups "has outlined what it says is a concerted effort by the multinational to dominate the seeds industry in the us and prevent farmers from replanting crops they have produced from Monsanto seeds". 
to adopt legal frames that conform to patent laws in the economically dominant countries of the world. Moreover, the transnational integration of the major patent offices in the United States, Europe and Japan has created a global network of knowledge governance that results in a "concealed" harmonization of patent laws (Drahos, 2010) $)^{33}$.

But patent protection is not just a technical or economic matter. Patent laws have social, political as well as economic implications. Intellectual Property Rights (IPR) are intended to offer incentives to stimulate innovation (Stiglitz e Greenwald, 2014, pp. 429-456) ${ }^{34}$. The counterpart to intellectual property rights is the public domain. William Landes and Richard Posner (2003, pp. 14-15) note that even the strongest defenders of property rights "acknowledge the economic value of preserving public domains - that is, of areas in which property is available for common use rather than owned - even in regard to physical property and a fortiori in regard to intellectual property".

A debate surrounding intellectual property rights that is just starting ( $\mathrm{Li}$, MacGarvie e Moser, 2015) but is getting more intense concerns the extent to which scientific texts, for example, are made freely available by companies (such as Google, Academia or Research Gate) or libraries, to the dismay of publishers and authors ${ }^{35}$. Opponents to free access see these developments as a one-sided privilege favoring the "consumers" of texts and neglecting the rights of the "producers" of the respective intellectual accomplishments. Supported by law and court decisions,

33. The resistance by NGOs to Trips-inspired legislation is chronicled in Matthews (2011).

34. Economic or innovation-centered perspectives have indeed dominated the discussion about patents. More recently, a broader view relies on a "rights-based" perspective. As Stephen Hilgartner (2002, p. $945)$ argues, "decisions about intellectual property are about much more than simply finding ways to stimulate and reward innovation; they are also about accountability, control, and governance" leading to a politics of patents conception.

35. Consider the following recent example: "During the past few years, as the cost of TV rights for sporting events has escalated apparently without limit, so has the ease by which conventional broadcast methods can be circumvented. Despite the best efforts of global authorities, including the City of London Police's Intellectual Property Crime Unit (Pipcu), the proliferation, accessibility and reliability of sport streaming sites have only increased. 'Historically, most arrests and attempted prosecutions are made under the provision of the Copyright, Designs and Patents Act 1988, which prohibits the broadcast of material without the license of the copyright owner. However, in February 2012, during a case between the Premier League and a pub landlady from Portsmouth named Karen Murphy, the European Court ruled that live sporting events could not be regarded as 'intellectual creations'. They were instead 'subject to rules of the game, leaving no room for creative freedom'. The court decided that 'accordingly, those events cannot be protected under copyright"'. See http://www.theguardian. $\mathrm{com} /$ football/2015/aug/01/faster-easier-free-illegal-football-streams, accessed August 1, 2015, and http://www.theguardian.com/media/2012/feb/24/pub-landlady-karen-murphy-premier-league, accessed August 1, 2015. 
libraries in Germany, for example, are permitted to scan textbooks and make them available for students to save on sticks - which of course allows them to pass them on without restrictions ${ }^{36}$.

Critical issues surrounding patents involve the question whether patents actually stimulate innovation (Williams, 2016 for an empirical investigation of he issue in the health care market), the extent to which patents add to the price the consumer has to pay (for example, for pharmaceuticals), the meaning of a fencingin of knowledge, in the first place, which we have discussed, or the scope and the degree of novelty demanded for granting a parent. Answers to these issues are highly contestable. Every invention that is granted legal protection for a limited period of time of course relies on previously accumulated knowledge (Stiglitz, 1999, pp. 314-316; Stiglitz, 2012, p. 78). "Because patent lawyers are masters of obfuscation", as the Economist (“Time to fix patents", August 8, 2015) argues, patents in fact tend to slow innovation by slowing the dissemination of knowledge; patents tend to lock in the advantages of the patent holders. Hence the conclusion that follows from critical questions about the role of patents would seem to be that the patent system should not be enhanced but reduced in its impact, if not abolished

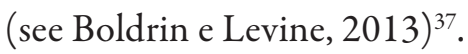

Private intellectual property rights (IPR) now widely employed by law-makers at international (Fink e Maskus, 2005), national and regional levels are not restricted to patents but also extend to copyrights (which, in contrast to patents, are acquired almost instantly upon creation), databases (David, 2000), trademarks, designs, software (see Harison, 2008; Bonaccorsi, Calvert e Joly, 2011), plant varieties, and trade secrets (in the sense of information and knowledge held by a business that is kept out of the public domain through agreements with employees or other firms) ${ }^{38}$.

It is not surprising therefore to observe that there are many types of intellectual property rights and many types of institutions that deal with their administration. The variety of intellectual property rights and the ways they interrelate with law,

36. See Roland Reiss, "Eine Kriegserklärung an das Buch” [A declaration of war on books], Frankfurter Allgemeine Zeitung, October 13, 2015.

37. Michele Boldrin and David Levine (2013, p. 3) sum up their case against the economic efficacy of patents as follows: "There is no empirical evidence that [patents] serve to increase innovation and productivity, unless productivity is identified with the number of patents awarded - which, as evidence shows, has no correlation with measured productivity".

38. We have to recognize - although this attribute of the concept of intellectual property is not part of our analysis of the value of knowledge - that the notion of intellectual property is an essentially contested concept across different cultures, for example, in cultures that mainly rely on oral or written transmission (Garmon, 2002) or in societies that recognize hybrid ownership between strictly individual and strictly collective (public domain) ownership (e.g. Strathern, 2005; Ghosh e Soete, 2006; for the case of software, see Ghosh, 2005). 
markets, corporations and individuals makes it most difficult if not impossible to gain a robust general insight into the value of (distinctive) ideas, inventions, knowledge and copyrights ${ }^{39}$. The propensity to attempt to patent an invention or, on the contrary, to make ideas freely available depends on the social context in which new knowledge is discovered. For example,

[...] using data collected by the National Research Council within the U.S. National Academies from their survey of firms that received National Institutes of Health Phase II Small Business Innovation Research awards between 1992 and 2001, (Link e Ruhm, 2009) find that entrepreneurs with academic backgrounds are more likely to publish their intellectual capital compared to entrepreneurs with business backgrounds, who are more likely to patent their intellectual capital (Link e Ruhm, 2009, p. 1).

The benefits that accrue to intellectual property may arrive in many ways, depending on the nature of the invention (such as a license granted or the signal a patent sends to others, see Long, 2002). After all, Research and Development (R\&D) efforts are inherently heterogeneous, sometimes successful, at other times without valuable results and "there is a large variance in the value of individual patents, rendering patents counts an extremely noise indicator of R\&D success" (Czarnitzki, Hall e Oriani, 2006, p. 124). At best, we will be able to arrive at an indirect and ambivalent assessment, especially with respect to quantity, of the value and costs associated with intellectual proper rights ${ }^{40}$.

In the strict sense of the term, knowledge tends to be embedded only in patents and not in trademarks. Trademarks are names affixed by a company to their products or similar attributes; hence, based on our definition of information, trademarks convey information. From an economic perspective, a patent - if well enforced -

39. For this reason, one may infer, the European Commission and the other international organizations in their report System of National Accounts 2008 (2009, p. 263) conclude, "originals of intellectual property products, such as computer software and entertainment, literary or artistic originals should be entered at the written down value of their initial cost, revalued to the prices of the current period. Since these products will have often been produced on own account, the initial cost may be estimated by the sum of costs incurred including a return to capital on the fixed assets used in production. If value cannot be established in this way, it may be appropriate to estimate the present value of future returns arising from the use of the original in production" (our emphasis).

40. 157 U.S. universities responding to a 2011 survey of the Association of University Technology Managers reported an earned income of "more than \$1.8-billion from commercializing their academic research in the 2011 fiscal year, collecting royalties from new breeds of wheat, from a new drug for the treatment of HIV, and from longstanding arrangements over enduring products like Gatorade". See G. Blumenstyk, "Universities Report \$1.8-Billion in Earnings on Inventions in 2011", Chronicle of Higher Education August 28, 2012. 
represents a monopoly that offers a rent to the owner. In the context of examining the value of knowledge, we are interested in the rent patents may generate ${ }^{41}$.

As Margaret Blair and Steven Wallman (2001, p. 73) in their report on "unseen wealth" point out, "once an intangible [such as a copyright] has been defined by law as a piece of property, and the rights associated with that property have been delimited, it becomes easier to estimate a value associated with those property rights and to sell, or transfer, or enter into other transactions involving that piece of property”. Assigning property rights to an invention, a text, a musical score or software does, as such, not immediately allow for an assessment of the value of intellectual property. In fact, the value of intellectual property could be zero or even negative if the investment afforded for generating the invention is never returned. Presumably, not all patents are successful. The value will be a function of the many additional features related to the activity of the owner, for example his willingness to invest in activities protecting the monopoly or, last but not least, of the nature of the intellectual property itself.

From an economic perspective, a patent enshrined in law represents a capacity to act and a solution to the "appropriability problem" (a protective function for new knowledge) or is seen to offer an answer to the free-rider issue since knowledge is viewed as "non-excludable". Patent protection translates non-rival goods into excludable goods. Only the patent holder is legitimized to appropriate the benefits of the invention. Others are excluded from enjoying the profits of the knowledge in question. In addition, from an economic point of view, patents are seen to serve as an incentive to produce socially and economically desirable innovations.

Patent laws are powerfully influenced by assumptions about knowledge and innovation from neo-classical economics (see Dempsey, 1999). But a comprehensive theory of the economic effects of patents must also take into account that legal intellectual property protections can restrain rather than encourage innovation, the growth of knowledge and socio-economic development. If knowledge is defined as a public good (Stiglitz, 1995; Zhou, 2015), that is, as non-rival in use and non-excludable in consumption, the ideas associated with knowledge claims "may even stimulate others to have an idea with large commercial value" (Stiglitz, 1999, p. 309 ${ }^{42}$. On the other hand, profit-oriented actors would not be interested in

41. Whether or not monopolies are a burden on value-adding activities or even encourage desirable innovations or lead to overpricing and undersupply, is not at issue in our examination of patents (but see Nordhaus, 1969; Boldrin e Levine, 2005; Crampes e Langinier, 2009).

42. As a matter of practical considerations, the strength, the design and the range of intellectual property rights has a strong influence on the "extent to which innovation adds or subtracts from the pool of ideas that are available to be commercially exploited, i.e. to technological opportunities” (Stiglitz, 2014, p. 1; 2010). 
entering into the production of public goods because they could not make a profit (Archibugi e Filippetti, 2015, p. 481). André Gorz (2003) ${ }^{43}$ defends the desirability of treating knowledge as a common good on the basis of a couple of considerations: (1) Knowledge is from the outset the product of collective labor, (2) knowledge does not have the attributes of commodities that escape the owner's control upon being sold or losing legal control and (3) privatization would restrict the societal utility of knowledge. But as Charlotte Hess and Elinor Ostrom (2007, p. 5) warn, a common good leads to conduct "such as competition for use, free riding and overharvesting"; and "[ $\mathrm{t}$ ]ypical threats to knowledge commons are commodification or enclosure, pollution and degradation, and nonsustainability". Even if you declare and understand that knowledge is a common good what remains is the difficult task and process to devise and learn effective ways with the help of which knowledge can be shared ${ }^{44}$. Such a demand is of course at the core of every educational effort.

In a "well-functioning" economy the monetary value of an individual good should be represented by its price. Many efforts have been made to accomplish exactly this. Most often efforts to establish the value of intellectual property are based on the use of proxies $^{45}$. For example, the value of IPR are inferred from the value of the prices of shares of a company listed on the stock exchange, thus establishing IPR as part of the "unseen wealth" of a corporation. Intangibles "can be related to brand names, process or product innovations, advertising, managerial skill, human capital in the workforce, and other aspects of the firm" (Greenhalgh and Rogers, 2007, p. 551; also Van Eckelen, 2015) ${ }^{46}$. Such arithmetic indicates that highly contentious figures could result from such an effort. It is virtually impossible to arrive at a robust conclusion regarding whether such an accounting under- or overestimates the value of the intellectual property of a firm. In short, "the eventual returns to individual patents or trademarks can vary enormously: most returns are very small, but a few generate huge returns".

43. Interview with André Gorz, "Entsinnlichung des Wissens" [The loss of meaning of knowledge]. Die Tageszeitung, August 8, 2003.

44. As Alfredo Macias Aazquez and Pablo Alonso Gonzalez (2016, pp. 46-47) note in general terms, "it would be crucial to organize cooperative and relational processes grounded in non-exclusionary and non-divisible principles, Likewise, it would be necessary to development mechanisms of ownership regulation that are not solely underpinned by anonymous criteria supported by legal provisions that have a single set of terms to all users".

45. There are of course legal means for enforcing the rights inherent in a patent, trademark and copyright. The recognition of the considerable economic value and, perhaps, also economic power and prestige has led to an increase in litigation activities in the context of IPRs (Hoti e McAleer, 2006).

46. Bregie van Eckelen (2015, p. 447) investigates "what conditions need to be met for knowledge to be incorporated as a new category of value, and whether these conditions (such as separability, commensurability and appropriability) differ from the accounting requirements for more tangible capital". 
What is possible, however, is to revert to the broad collective income and the expenditures of royalty and license fees received and paid by entire nations. The World Bank $(2015)^{47}$ offers such statistics for a wide range of countries. And as recent data from the "2014 World Development Indicators" show, the "Balance of Technology Trade" is heavily tilted in favor of a few countries whose expenditures on Research and Development, as percentages of the national Gross National Product (GNP), have been high (also Ganguli, 2000).

Large expenditures on research and development (R\&D) in a country appear to ensure that the balance of royalty and license fees received is positive (e.g. in the case of Finland, Germany, Japan, Sweden, the United Kingdom and the United States) while comparatively low R\&D expenditures correlate with a negative balance (e.g. in the case of Brazil, Canada, Ireland, Portugal and Russia). But there are cases where this correlation does not hold, for example in the case of Austria where high R\&D expenditures coexist with a negative balance of royalty and license fees both in 2007 and 2014. In many instances of nations with a significant balance of inter-nation technology trade, the gap has increased in recent years (e.g. Canada, Austria, India, Italy and Korea) $)^{48}$.

The statistic of the inter-nation technology trade balances does not allow for a precise inference of many relevant data regarding the value and costs of intellectual property rights. It provides only a very broad indication that such rights are translated into national monetary advantages; that both payments and receipts of royalty and license fees tend to increase in more recent years; that disadvantages and benefits are unequally distributed across the globe; and about the size of the receipts and payments. The conclusion that can be drawn is that the economic role of intellectual property rights is increasing measurably, signifying the transformation of national economies into what is at times designated as knowledge-based economies.

47. See http://databank.worldbank.org/data//reports.aspx ?source=2\&Topic $=14$.

48. In the 2009 publication of the System of National Accounts, one finds the follow cautionary note, "the value of research and development ( $R \& D$ ) [which does not include the value of human capital] should be determined in terms of the economic benefits it is expected to provide in the future. This includes the provision of public services in the case of $R \& D$ acquired by government. In principle, $R \& D$ that does not provide an economic benefit to its owner does not constitute a fixed asset and should be treated as intermediate consumption. Unless the market value of the R\&D is observed directly, it may, by convention, be valued at the sum of costs, including the cost of unsuccessful R\&D" (European Commission et al., 2009, p. 206; emphasis added). 
Taxation, or the price of education ${ }^{49}$

It is not only the professional but also the common-sense view that citizens of democratic societies should be knowledgeable and well informed. Being knowledgeable and well informed comes at a price. One avenue that is open to social scientists interested in the question of the price of knowledge is to examine specific contested cases in which the question of the price of knowledge does play a role, if only an indirect one. We will describe such a conflict about the resources that should be mobilized by the state to ensure that its citizens acquire the level of knowledge and information that is deemed desirable for a democratic society ${ }^{50}$.

During the last century the relation between education and democracy had become almost conventional wisdom. John Dewey ([1916] 2005), for example, views broad if not high levels of educational attainment as a precondition for democracy; while in the post-war era, Seymour Martin Lipset's (1959, p. 80) cross-national empirical study comes to the conclusion that "high" levels of educational achievement are a necessary condition for the existence and stability of a democratic society. Even more recent empirical work tends to support this conclusion (e.g. Barro, $1999 \mathrm{e}$ Przeworski et al., 2000). An examination of the role and experience of science advising and science policy formation in the United States in the late 1950s (last but not least in the wake of the launch of the first manmade satellite, Sputnik, by the Soviets in the fall of 1957) emphatically concludes that "a democratic nation can only cope with the scientific revolution if thoughtful citizens know what it truly entails" (Dupré e Lakoff, 1962, p. 181).

However, it is also John Dewey ([1916] 2005, pp. 108-110) who warns against treating education as a black box. High levels of formal education are indeed compatible - as the case of Germany demonstrates - with an authoritarian personality and an elevated deference to the state. Dewey ([1916] 2005, p. 57) notes that in the case of the German educational system, "the educational process was taken to be one of disciplinary training rather than of personal development [...] only in and through an absorption of the aims and meaning of the organized institutions does [the individual] attain true personality". In other words, the philosophy of education and the aims of the educational system "required subordination of individuals to the superior interests of the state". The subservient personality as the primary

49. An initial discussion of the taxation-regime perspective on the price of knowledge can be found in Stehr, 2015.

50. The discussion in the scientific and legal literature of the "direct" taxation of knowledge or intangible resources is in its infancy (see Simkovic, 2015). The only discussion we could find of the practice of taxation, in the United States in this case, is a brief article by Luscombe (1996). 
goal to be realized by educational policies not only in imperial Germany but for decades to come required a "thoroughgoing 'disciplinary' subordination to existing institutions". Dewey's observations are a useful reminder that a high formal level of education in a society does not necessarily lead to support for democratic values and conduct. The association between formal educational achievement and democracy is a complex relationship that requires careful attention to the nature of the actual education system.

This raises the question of how much knowledge and information the citizen of modern societies needs to acquire, and the related issue of the volume of the resources the state has to invest to accomplish such an outcome. There can be little doubt that these questions are highly complex and contentious, as the long-lasting conflict between the State of New York and the City of New York over educational finances readily demonstrates ${ }^{51}$.

For over a decade, the State of New York and the City of New York were entangled in a legal battle over the question of whether the State of New York provided fair and sufficient financial means for the gigantic public school system of the City of New York ${ }^{52}$. The legal dispute ran its course parallel to the so-called "educational standards movement" which has been fighting for the continual improvement of the expectations and standards attached to a high school diploma. In a number of American states, for example Kentucky, courts have indeed prescribed much higher, clearly defined standards.

51. A comparable and equally drawn-out legal dispute between the State of New Jersey and plaintiffs who argued that the state provided inadequate funding to some school districts in order to ensure the "provision of educational services sufficient to enable pupils to master the Core Curriculum Content Standards" was settled by the Supreme Court of New Jersey on May 24, 2011 in favor of the plaintiffs. The court enjoined the State of New Jersey to increase state education aid by $\$ 500$ million in the coming school year, distributed among 31 school districts in historically poor cities. The Court concluded that the State failed to meet its constitutional burden to make sure that a "thorough and efficient education" was provided. The New Jersey constitution indeed charges the State with the fundamental responsibility to educate schoolchildren: "The Legislature shall provide for the maintenance and support of a thorough and efficient system of free public schools for the instruction of all the children in the State between the ages of five and eighteen years" (N.J. Const. art. viII, $\$ 4,1$.). The fundamental right to an adequate education extends to all children in the State. The court relied in its decision on Special Master's Opinion/Recommendations to the Supreme Court, submitted by Judge Peter E. Doyne (source http://www.judiciary.state.nj.us/opinions/index.htm and Winnie $\mathrm{Hu}$ and Richard Pérez-Peña, "Court orders New Jersey to increase aid to schools". New York Times, May 25, 2011).

52. We rely on the accounts of the conflict between the State of New York and the City of New York found in the New York Times, especially the article dated June 30, 2002 ("Johnny can read, not well enough to vote?"); and subsequent coverage in the same newspaper, especially "School financing case argued before State's highest court”. New York Times, October 11, 2006 (also Scherer, 2004-2005). 
At first glance, this is apparently one of those everyday rhetorical disputes between different political jurisdictions over contested questions of revenue sharing between various political levels - a familiar occurrence in any democratic society. The State of New York provides approximately half of the school budget for the City of New York. One of the most recent judgments in this legal action, however, has made reference to a fundamental philosophical or constitutional problem: Which skills, information and proficiencies should the modern state be minimally obligated to successfully convey to students in its schools; and how expensive must an education system be that guarantees standards of this type? The developments in the New York dispute make it evident that this conflict over how to answer the question under debate is ultimately based on a problem that must be decided within the political system.

The constitution of the State of New York stipulates that the State is obligated to guarantee "the maintenance and support of a system of free common schools wherein all the children of this state may be educated". The interpretation of this constitutional norm as an obligation for the state to make possible a "sound, basic" education is concretized by the Court of Appeals of the State of New York, in a 1995 judgment. This court further ruled that the public school system must be in a position to guarantee that students "function productively as civic participants capable of voting and serving on a jury". In a later judgment of 2001, a judge of the Constitutional Court of the State of New York ruled that as jurors, citizens are required to answer complex questions: Jurors "must determine questions of fact concerning DNA evidence, statistical analysis and convoluted financial fraud, to name only three topics". The State successfully appealed this judgment.

In June 2002, however, the Appellate Division of the State Supreme Court of New York defined a restrictive interpretation of this constitutional norm: On the basis of relevant constitutional standards, the State is not obliged to finance more than a minimal education. More concretely, after eight or nine years, students should be able to read political parties' campaign literature; serve the courts as jurors; and fulfill the requirements of an employment that makes minor demands on them. The high school diploma should only ensure that the student had acquired the ability "to get a job, and support oneself, and thereby not be a charge on the public fiscus".

The court's decision was variously received: In some quarters, this minimal educational requirement was understood as a kind of capitulation on the part of the State. In others, the judges were praised for their wise decision, since (more) money was not necessarily an adequate solution to the educational dilemma - other factors also influenced students' opportunities of acquiring cultural capital. The court emphasized that its task had been only to determine the citizen's minimum rights 
to education as laid out in the constitution; this minimum demand is indeed met by the schools of the City of New York. A claim for compensatory education, for instance, is therefore untenable. And to the extent that the citizens disagree with these minimum goals, they will have to replace the responsible politicians by electoral means. The plaintiff, The Campaign for Fiscal Equity, filed an appeal.

Could this ruling by one of the highest courts of the State of New York be an arbitral verdict that reflects the spirit of the industrial rather than the knowledge society, that is, what matters is that its citizens are able to find their way to the voting booth and function as a juror?

The legal dispute finally ended (with no possibility of appeal) on November 20, 2006 with a verdict by the highest court of the State of New York, the Court of Appeals, in which the State of New York was ordered to provide an additional 1.93 billion dollars annually for the city school system. This sum is considerably less than the 4.7 billion dollars that a lower court had ruled to be appropriate. The final judgment was based on the recommendation of a commission appointed by New York State Governor Pataki in 2004. In a dissenting opinion from that of the majority of the court, one of the two judges in the minority states that "a sound basic education will cost approximately $\$ 5$ billion in additional annual expenditure. I remain hopeful that, despite the court's ruling today, the policymakers will continue to strive to make schools not merely adequate, but excellent, and to implement a statewide solution". The four judges responsible for the court's majority verdict were all appointees of then New York Governor George Pataki (1995-2006).

\section{Additional knowledge}

Additional knowledge enlarges our capacity to act; thus novel or additional knowledge may be of particular value. It is unavoidable that knowledge has political as well as economic attributes. Knowledge as a capacity to act contributes to what is constitutive for politics: to change or to preserve and perpetuate. In general, therefore, knowledge is a medium of social control because once deployed it may structure and restructure social formations. In the context of the knowledge-based economy in modern societies (Stehr, 2002), knowledge becomes a force of production, displacing the forces of production typical of industrial society, namely property and capital, and therefore a source of additional value, economic growth and productivity including, of course, the possibility of a transition to a sustainable economic system.

The science system in modern societies is by definition a core part of the set of societal institutions that generates additional knowledge. The prestige, the exceptional social, economic and intellectual importance of scientific knowledge is 
firmly associated with the capacity of the social system of science within which it is embedded to fabricate additional knowledge claims. In modern societies, scientific and technical knowledge is uniquely important because it produces incremental capacities for social and economic action, or an increase in the ability of "how-todo-it" that may be "privately appropriated", at least temporarily ${ }^{53}$. In social institutions other than science, routinized, habitual conduct and the interpretation and defense of established intellectual perspectives are constitutive. In science, invention and therefore the production of knowledge beyond what already exists is the prime function of the social system of science.

Contrary to neoclassical assumptions, in the case of the economic importance of knowledge in general and additional knowledge in particular the unit price for knowledge-intensive commodities and services decreases with increased production, reflecting "progress down the learning curve" (Schwartz, 1992; see also the economic implications of learning by doing, Arrow, 1962b). Incremental knowledge is just as heterogeneous as is socially widely accessible knowledge. Thus it is entirely conceivable that incremental knowledge may, at any given time, include "key findings" that will prove to be especially valuable in many respects, as for example in economic, military or political contexts. Which knowledge will become key knowledge can only be determined empirically (see Stehr, 2000).

Knowledge constitutes a basis for power. Knowledge excludes. As John Kenneth Galbraith (1967, p. 67) stresses with justification, power "goes to the factor which is hardest to obtain or hardest to replace [...] it adheres to the one that has greatest inelasticity of supply at the margin". But knowledge as such is not a scarce commodity, though there is one feature of some knowledge claims that may well transform knowledge from a plentiful into a scarce resource: what is scarce and difficult to obtain is not access to knowledge per se, but access to incremental knowledge, to a "marginal unit" of knowledge. The greater the tempo with which incremental knowledge ages or decays, the greater the potential influence of the social system within which additional knowledge is produced and the greater the social importance and prestige of those who manufacture or augment knowledge; and, correspondingly, of those who transmit (moderate) such increments to other social systems.

53. Peter Drucker (1993, p. 184) observes that the initial economic advantages gained by the application of (new) knowledge become permanent and irreversible. What this implies, according to Drucker, is that imperfect competition becomes a constitutive element of the economy. Knowledge can be disseminated or sold without leaving the context from which it is disseminated or sold. The edge that remains is perhaps best described as an advantage based on cumulative learning. The matter is even more complicated by virtue of the possibility that the acquisition of incremental knowledge may mean that "the buyer does not know what she is buying, and not need the product when she knows" (Eggertsson, 2009, p. 138). 
If sold, knowledge enters the domain of others; yet it remains within the domain of the producer and can be spun off once again. This signals that the transfer and the absorption of knowledge do not necessarily include the transfer of the cognitive ability to generate such knowledge, for example, the theoretical apparatus, the technological regime or the required infrastructure that yields such knowledge claims in the first place and is the basis for them to be calibrated and validated. Cognitive skills of this kind, therefore, are scarce. Economists often take it for granted that the fabrication of knowledge is expensive whereas its dissemination is virtually without cost. This view is further supported by the common conviction that technological knowledge is nothing but a blueprint that is readily usable, at nominal cost, for all.

However, the acquisition of the kinds of cognitive skills needed to comprehend knowledge and technology can be quite expensive. For example, in many cases, only the rough outlines of technical knowledge are objectified or codified by non-personal means of communication (Berrill, 1964). As a result, some economists suggest that the dissipation and absorption of knowledge, or at least some forms of knowledge, is more costly than its production (see Stigler, 1980, pp. 660-641). Such a conclusion, as well as evidence supporting this observation (Teece, 1977), raises the question of whether the fabrication of knowledge can be easily separated from its dissemination, in terms of reproduction, in the first place.

The progressive elimination of time and space as relevant elements in the production of knowledge has paradoxically injected the importance of time and location into the interpretation and use of (objectified) knowledge. Since the mere understanding and the validation process of knowledge cannot, except in rare circumstances, refer back to the original author(s) of the claim, the separation of social roles makes the interpretive tasks carried out by "experts" more crucial. Knowledge must be made available, interpreted, and linked to local, contingent circumstances. The complexity of the linkages and the volume of the resources required to enact capacities for action delineate the limits of the power of scientific and technical knowledge. Such limits are an inevitable part of the fabrication of scientific knowledge and explain why, generally speaking, the knowledge work performed by the stratum of experts in knowledge-based occupations attains greater and greater centrality in advanced societies. The social prestige, authority and influence of experts are heightened, moreover, if their claim to expertise is uniquely coupled with access to additional knowledge (see Grundmann e Stehr, 2012).

The centrality of knowledge-based occupations or, to use a narrower term, of experts in knowledge societies does not mean that we are on the way, as social theorists have feared in the past, to a technocratic society or a technical state. A technocratic model of society and its major social institutions, which "sees technicians 
dominating officials and management, and which sees the modern technologically developed bureaucracies as governed by an exclusive reliance on a standard of efficiency" (Gouldner, 1976, p. 257), be it a nightmare or a utopia, is a counterintuitive scenario. It is doubtful whether the crucial choices that modern societies will be forced to make are more about the technical means and less about the competing ends of social action.

Quite a number of arguments can be deployed to demystify the threat of technocracy and a new ruling class made up of faceless experts. The most persuasive argument is social reality itself, which has failed to support the transformation of society in this direction. The long-predicted emergence of technocratic regimes has not materialized. The diagnosis of an imminent and menacing technocratic society was greatly overdrawn.

Michel Crozier offers a less obvious argument about the limits of the power of experts, counselors and advisors in his study of the bureaucratic phenomenon. Crozier ([1963] 1964, p. 165) argues that the power of an expert is self-curtailing and self-defeating:

The rationalization process gives him power, but the end results of rationalization curtail his power. As soon as a field is well covered, as soon as the first intuitions and innovations can be translated into rules and programs, the expert's power disappears. As a matter of fact, experts have power only on the front line of progress - which means that they have a constantly shifting and fragile power.

The objectification and routinization of incremental knowledge curtails the power of knowledge. Yet knowledge assimilated to power is most likely incremental knowledge. Crozier's vision of the "natural" limits of the power of experts, however, is still animated, if only implicitly, by the idea that experts - temporarily and exclusively - command uncontested knowledge, that their clients fully trust expert knowledge, and that experts therefore do not get enmeshed in controversies.

But the growing importance of knowledge-based occupations in modern society does not mean that the trust of the public in experts, advisers and consultants (Miller, 1983, pp. 90-93) is growing at the same pace or is not contingent on relationships (Wynne, 1992). On the contrary, we believe less and less in experts, although we employ them more and more. Yet without some element of trust in experts exhibited by ordinary members of society, expertise would vanish.

Nonetheless, experts today are constantly involved in a remarkable number of controversies. The growing policy field of setting limits to the presence of certain ingredients in foodstuffs, of safety regulations, risk management, and hazard con- 
trol has had the side effect of ruining the reputation of experts. As long as an issue remains a contested matter, especially a publicly contented matter, the power and influence of experts and counter-experts is limited (see Nelkin, 1975, 1987); once a decision has been made and a question has been settled, the authority of experts also becomes almost uncontested. The work required to transform a contested matter into an uncontested matter is linked to the ability of experts to mobilize social and cultural resources in relevant contexts (see Limoges, 1993).

How knowledge and its role are defined in a particular context is determined by individual actors as well as by the legal, economic, political, or religious constructs that have gained authority. Moreover, the nature of the interaction, whether private or public (see van den Daele, 1996), the issue or practices at hand, and the audiences concerned are crucial in deciding what knowledge is mobilized and how it is enacted. Defining the role of knowledge is increasingly the job of experts, counselors, and advisors. The group of occupations designated here as experts, counselors and advisors is required to mediate between the complex distribution of knowledge that keeps changing and those who seek for knowledge. Ideas tend to travel as the baggage of people, as it were, whereas skills, in the sense of know-how and rules of thumb, are embodied or inscribed in them. Studies of innovation processes have shown how important the close coupling of social networks is for knowledge transfer as well as for the ultimate success of innovations in economic contexts; the studies indicate that the traffic of people within and among firms, for example, is crucial to the process of knowledge transfer (e.g. DeBresson e Amesse, 1991; Freeman, 1991; Callon, 1992; Faulkner, Senker e Velho, 1995).

A chain of interpretations must come to an "end" in order for knowledge to become relevant in practice and effective as a capacity for action. This function of putting an end to the process of reflection - or of healing the lack of immediate practicability that is inherent to scientific and technical knowledge as it emerges from the scientific community - for the purpose of action is largely performed by various groups of experts in modern society. Their societal prominence today is intimately related to the central role of knowledge for contemporary society.

But aside from the question of the nature of practical and additional knowledge, it is important to briefly reflect about what can only be called the uneven development of knowledge. For example, while we may well have a surplus of knowledge in fields such as bioengineering, weapons know-how, or psychological knowledge designed to manipulate and persuade by hidden means, there are pressing social, political or health issues that remain unsolved due to our lack of knowledge.

The differentiation between common sense or everyday knowledge and expert or scientific knowledge is the most frequent difference among forms of knowledge 
that one typically encounters both in everyday life and in the scientific community. The difference is most often asymmetrical. Objective knowledge enhances and embellishes itself by pointing to the deficiencies of common-sense knowledge. The deficits of non-scientific knowledge are legion. Everyday knowledge is superficial, if not unreflective and false. In many analyses, as a result, the elevated social role of scientific and technological knowledge is almost invariably tied to its superior attributes. The deficiencies of common-sense knowledge, in turn, account for its inferior, if not declining, status and function in modern societies. But one certainly must wonder how it is that everyday knowledge, given such inherent deficiencies, has managed to survive in modern societies. In response, we do not want to collapse or dispense with the difference between everyday and scientific knowledge (see Shapin, 2001). But in contrast to the common-sense distinction between lay and expert knowledge, we want to make the case that the many characteristics that justify the rise of scientific knowledge above the multiple insufficiencies of common-sense knowledge are helpful in accounting for what is undoubtedly the greater social, intellectual and economic importance of scientific knowledge in modern societies.

Knowledge as a public good

Knowledge is perhaps the quintessential public good. Peter Drahos (2004, p. 321)

One further consideration in our search for the price of knowledge relates to the claim that knowledge is, in the end, actually a public good. Should Peter Drahos' thesis that knowledge is an essentially public good be correct, then the question of the price of knowledge (as a public good) can be answered promptly and, of course, correctly: knowledge is without a price.

Joseph Stiglitz (1999) describes why knowledge is not merely a public good but a global public good ${ }^{54}$. Most if not all discussions about knowledge as a public good are normative or political in nature since economists tend to strongly defend either the idea that knowledge should be available to all (for different reasons, obviously) or the idea that knowledge, for example additional knowledge, needs to be protected

54. Joseph Stiglitz (1995) identified a total of five global public goods: "international economic stability, international security (political stability), the international environment, international humanitarian assistance and knowledge". A definition of global public good that is not merely confined to identifying examples of global public goods but also considers their availability concludes that "global public goods might usefully be defined as those goods (including policies and infrastructure) that are systematically underprovided by private market forces and for which such under-provision has important international externality effects" (Maskus e Reichman, 2004, p. 284). 
and hence carry a price tag (again for difference reasons but mainly to ensure that the propensity to generate additional knowledge is not being stifled).

But first, what is a public good and why is the idea of a public good related to the issue of the price of a public good? Public goods are very diverse phenomena. Economists consider products/knowledge/services/ideas/information that are produced or available in a society to be public goods if access to them is not regulated and can in principle be shared by all members of a community. Street names, trust or safety are public goods. Public goods, therefore, emerge as a result of certain social norms (such as, for instance, peace, civic order, and good governance) or are physical phenomena (such as, for instance, carbon-absorbing forests or algae, air).

The price of private goods is negotiated in market places. Market places are also seen as the most efficient context for furthering the propensity to produce private goods. The propensity to produce is further secured by conditions extraneous to the market, for example, property or intellectual rights; producers rely on public goods or non-market goods such as the air to breathe, the climate, national defense, or gravity.

Public goods are freely available by definition, they are not subject to property rights, and their burdens or benefits cannot be restricted to an individual or a collectivity. As far as their use or utility is concerned public goods are non-excludable. Moreover, the consumption of a public good is non-excludable if unauthorized actors (free-riders) cannot be prevented from enjoying the benefits or incurring the costs of being exposed to it. The non-excludability of a good, a service or an environmental condition is a contingent matter; for example, "it is easier to exclude individuals from the use of a bike than it is from national defense" (Drahos, 2004, p. 324).

If many individuals and organizations can enjoy a public good without depleting it and if its consumption or enjoyment does not come at another person's expense, a public good is non-rival. From an individual perspective, the consumption of public goods carries no restrictions. A mathematical theorem "satisfies both attributes: if I teach you the theorem, I continue to enjoy the knowledge of the theorem at the same time that you do" (Stiglitz, 1999, p. 308). Once the theorem is published, no one can be excluded, anyone can utilize it.

Joseph Stiglitz (1999, p. 309) also makes the point that the nonrivalrousness of knowledge implies, for example, that there is zero marginal cost for an additional individual or organization that benefits from available knowledge. Even if it would be possible to prevent someone from taking such knowledge on board, it would be undesirable to impose restrictions since there are no marginal costs associated with sharing the benefits that come with the knowledge in question.

Conflating knowledge and information, Stiglitz (1999, p. 309) argues that "if information is to be efficiently utilized, it cannot be privately provided because ef- 
ficiency implies charging a price of zero - the marginal cost of another individual enjoying the knowledge". However, as Stiglitz is quick to add, "at zero price only knowledge that can be produced at zero cost will be produced". In this case, private markets "would not provide them at all or would do so at deficient levels relative to those demanded by citizens" (Maakus e Reichman, 2004, p. 284). Hence, the probability that additional knowledge will be generated is also close to zero. If additional knowledge is without price, the supply of new knowledge will dry up. The idea that the acquisition of new knowledge comes at no cost of course describes an ideal typical condition. After all, the actual transmission and acquisition of additional knowledge requires some resources, however small or significant.

Nonexcludability also has implications for the price of knowledge. Since such knowledge is available to everyone, the price would approach zero. We have already discussed patents and intellectual property rights as ways of restricting the number of users. Depending on the legal frame of patenting, the patent application makes a considerable "amount" of the relevant innovation publicly accessible. Whether this knowledge can in fact be appropriated is not dependent on its mere availability, however.

The probability of fabricating incremental knowledge and enjoying the economic advantages that flow from such knowledge is, of course, a stratified and contingent process. Within technological regimes, techno-economic networks (Freeman, 1991; Callon, 1992) $)^{55}$ or theoretical "paradigms", the advantage goes to those who already have produced, and therefore command, significant elements of incremental knowledge. Technological regimes or paradigms may be embedded within a company or in a network of firms, research institutes, etc. In analogy to Merton's observations about the operation of the Matthew principle in the process of accumulating reputation and prestige in science, it is possible to stipulate a similar principle for the stratification of incremental knowledge. Generating incremental knowledge is likely to be easier for those who can disproportionately benefit from what they already know; for example, due to the capacity of combining local and global knowledge (Stiglitz, 1999, pp. 317-318).

The competitive advantages that may accrue to individuals or firms that generate and manage to control incremental knowledge is, without question, limited in terms of time, especially but not only due to the time limits of the protection granted by patents or copyrights. Thus, such companies must continuously strive

55. Michel Callon (1992, p. 73) defines techno-economic networks as a "coordinated set of heterogeneous actors - for instance, public laboratories, centres for technical research, companies, financial organizations, users and the government - who participate collectively in the conception, development, production and distribution or diffusion of procedures for producing goods and services, some of which give rise to market transactions". 
to stay ahead in the fabrication of knowledge ${ }^{56}$ : "Once they are imitated and their outputs standardized, then there are downward wage and employment pressures" (Storper, 1996, p. 257) as well as a decline in profitability ${ }^{57}$.

In contrast to incremental knowledge, the general, mundane and routinized stock of knowledge consists mostly of knowledge that is non-rival as well as nonexcludable, that is, these forms of knowledge may very well constitute public goods ${ }^{58}$. But even the general mundane stock of knowledge is hardly ever completely excludable or without rivalry, be it based either on legal norms or on some other apparatus in which it may be inscribed, preventing its use by others. From a collective point of view, for example from the perspective of all consumers or a community, the use of public goods, as noted early (see Hume [1739] 1961; Hardin, 1968), may give rise to the free-rider problem.

It might be useful to distinguish between pure public goods and quasi-public or impure public goods. Quasi-public goods would refer to conditions of action, for example, from which a consumer or an employer benefits even though she has not carried most of the cost of the asset. The publicly accessible infrastructure of a country would be an example, or an employee's training and education that is not entirely paid for by the employer but nonetheless of great benefit to the corporation.

As Inge Kaul, Isabelle Grunberg and Marc Stern (1999, p. xx) point out, financial stability has "public good qualities. A bank or financial institution can generate much profit through risky lending. All it stands to loose is its capital if it fails. But in a complex and interdependent financial system, the cost of a single institution defaulting are much higher - often a multiple - because one default can lead to more failures and

56. Existing or new companies can bring innovative products to the market and thus displace the products of competitors; or companies active in the market can improve their own products. A study by Daniel Garcia-Macia and colleagues (2016) shows that the much greater increase in employment (in the USA) is the result of the innovative activities of existing companies, in particular through the improvement of products. The improvement of production is therefore at least in this respect (and relatively short term) more important than the creative destruction of products.

57. William Starbuck's (1992, p. 716) definition of a knowledge-intensive firm resonates with these observations about the function of incremental knowledge since he stresses "exceptional and valuable expertise" rather than the possession of knowledge per se as constitutive of knowledge-intensive firms: "If one defines knowledge broadly to encompass what everybody knows, every firm can appear knowledge-intensive". However, these broad designations do not as yet represent operational measures of incremental knowledge or exceptional expertise.

58. These characteristics of knowledge allow for a decoupling of the "cost" of the fabrication of knowledge from the benefits that accrue to those who use it. As a result, the non-rival and non-excludable attributes of knowledge constitute a disincentive to invest in the production of knowledge (see Dosi, 1996, p. 83). Geroski (1995, pp. 94-100) discusses various strategies that might be instrumental in overcoming the appropriability problem of incremental knowledge. 
defaults". Technically, such a possibility is known as a case of negative externalities. But it is better known as a way of socializing costs. In the case of what is seen as global public goods, the costs and benefits, the externalities, are shared or borne across the world.

\section{Capital as embodied knowledge}

A final pathway in our exploration of finding a way of measuring the price of knowledge is to turn to the prominent idea within economics asserting that capital goods as opposed to financial or human capital are embodied knowledge (see Baetjer, 2000, p. 148).

The idea that capital, especially in the form of capital goods, is knowledge or at least is partly embodied knowledge, is more than doubtful. For the aquisition of financial and human capital includes knowledge. In many cases one could assert that the aquisition of financial capital and human capital incorporates knowledge to a greater degree than would be the case with many capital goods. Derivatives as financial goods are based on knowledge in the same manner as the intellectual capacities of an employer. For this reason, Gary Becker (Becker, Murphy e Tamura, 1994, p. 326) defines human capital as: "[people] embodied knowledge and skills, and economic development depends on advances in technological and scientific knowledge, development presumably depends on the accumulation of human capital".

That capital is embodied knowledge can already be found explicitly in a plausible example in Adam Smith's An inquiry into the nature and causes of the wealth of nations. In this volume, Adam Smith (p. 14) offers a clear example of how an idea enters into the construction of capital equipment ("frozen knowledge" [Boulding, 1996, pp. 5-6]), in this instance the early development of the steam engines. Concretely is an insight that becomes part of the design and hence the production of the engine; a design feature that makes the steam engine as a tool more efficient:

[...] a boy was constantly employed to open and shut alternately the communication between the boiler and the cylinder, according as the piston either ascended or descended. One of those boys, who loved to play with his companions, observed that, by tying a string from the handle of the valve which opened this communication to another part of the machine, the valve would open and shut without his assistance, and leave him at liberty to divert himself with his playfellows.

The observation by Adam Smith is generalized by members of the Austrian School of Economics; Carl Menger ([1871] 1981, p. 74) for example emphasizes: "The quantities of consumption goods at human disposal are limited only by the extent of human knowledge of the causal connections between things, and by the 
extent of human control over these things". From the basic observation of knowledge as knowledge incorporated into capital goods to a determination of the value of this knowledge, it is obviously a distant and complicated path which may not in the end lead to the desired goal. From the conventional terminology of economic theory it is very easy to infer the conclusion, as for example R. Harrod (1939, p. 18) underlines that the value of the capital can be determined relatively easily: the "actual saving in a period [...] is equal to the addition to the capital stock". Joan Robinson (1979, p. 100) in contrast is equally convinced that "no one ever makes it clear how capital is to be measured".

Without wishing to extend the discussion further, one can conclude with Howard Baetjer (2000, p. 169) that the value of the capital and thus the value of capital goods ultimately is not exactly measurable. And as long as it is difficult to determine the exact value of capital assets, it is clear that the value of the incorporated knowledge (as a part of such assets or products) is also not sufficiently determinable.

The general conclusion of the failure to discover the price of knowledge can be specified more precisely: (1) Incorporated knowledge can not only be very heterogeneous but also "invisible" (tacit knowledge). (2) Is it necessary to ask if knowledge stands in a symmetrical manner to other resources that constitute a capital good? (3) How to establish a relationship between other resources (or products) and knowledge in order to determine how much the share of knowledge is in the aggregate product? (4) How do we assess knowledge that has been incorporated at different temporal phases into production? (5) What is the value of knowledge given the loss of value of knowledge over a certain period of time and how can the loss of value (or profit) be determined? (5) If the value of a capital good is set in relation to its production output, these questions cannot be solved. (6) What is the effect of the complementary interaction of investment goods in production on the value of knowledge? (7) What is the importance of learning processes, including the learning of learning for the valuation of the capital goods, for example, in the case of software and thus knowledge? (8) Labor and capital form a (hybrid) unity in many economic contexts. What significance does this unit have for the value of knowledge?

\section{Conclusion: determining the price of knowledge}

Our investigation of how to put a "price" on knowledge interrogated various social science and practical perspectives for their usefulness in arriving at some arithmetic for determining the value of knowledge. Even if one tries to stick to established, manifest proxies of this somewhat opaque problem, it becomes increasingly clear how formidably obfuscated the matter presents itself, thus perhaps only emphasiz- 
ing the strong suspicion of many observers that knowledge simply cannot have or does not come with a price. It is not surprising therefore that the OECD (2006, p. 5) concludes its elaborate search for a way to quantify and measure "intangible assets" with the sensible recommendation that such assets including of course knowledge are "best dealt with through narrative financial reporting" (emphasis added).

We hope to have demonstrated, along the lines of our prior work on a sociological conception of knowledge, that knowledge, unless it is conveniently conflated with the category of information, is (1) embodied and thus hard to divorce from its carriers; (2) deeply entrenched in questions of social relations and thus stratification, both as a resource for other 'goods' as well as a 'product' of social circumstances; (3) does indeed play an ever greater role within as well as across (national) economies, but unfortunately in a manner that is anything but straight-forward; and that (4) the situation becomes even more complicated once these three dimension of our inquiry become entangled in a stand-off between individual, economic and public relevancies regarding the role and benefits of knowledge

\section{Bibliographic References}

Acemoglu, Daron \& Autor, David. (2012), "What does human capital do? A review of Goldin and Katz's The race between education and technology". Journal of Economic Literature, 50: 426-463.

AcкоғF, Russell L. (1989), "From data to wisdom”. Journal of Applied Systems Analysis, 16: 3-9. Adolf, Marian \& STEHr, Nico. (2014), Knowledge. London, Routledge.

Archibugi, Daniele \& Filippetti, Andrea. (2015), “Knowledge as global public good”. In: Filippetti, Andrea \& ArChibugi, Daniele (eds.). The handbook of global science, technology, and innovation. New York, John Wiley, pp. 479-503.

Arrow, Kenneth. (1962), “The economic implications of learning by doing”. Review of Economic Studies, 29: 155-173.

Atkinson, Anthony B. (1983), The economics of inequality. Second edition. Oxford, Clarendon Press.

Autor, David H. \& Handel, Michael J. (2009), "Putting tasks to the test: human capital, job tasks and wages”. NBER Working Paper, 15116. Available in http://www.nber.org/ papers/w15116.

Baetjer, Howard Jr. (2002), "Capital as embodies knowledge: some implications for the theory of economic growth". Review of Austrian Economics, 13: 147-174.

BALZER, Wolfgang. (2003), "Wissen und Wissenschaft als Waren”. Erkenntnis, 58: 87-110.

BARNEY, Jay B. (1991), "Firm resources and sustained competitive advantage". Journal of Management, 17: 99-120. 
BARro, Robert. (1999), “The determinants of democracy”. Journal of Political Economy, 107: 158-183.

BECKer, Gary S. (1994a), Human capital: a theoretical and empirical analysis, with special reference to education. Third edition. New York, National Bureau of Economic Research.

. (1994b), "Human capital revisited". In: Becker, Gary S. (1994), Human capital: a theoretical and empirical analysis, with special reference to education. Third edition. New York, National Bureau of Economic Research, pp. 15-28.

. (1993), "The economic way of looking at behavior". Journal of Political Economy, 101: 385-409.

. (1964), Human capital. New York, National Bureau of Economic Research.

. \& GERHART, Barry. (1996), “The impact of human resources management on organizational performance: Progress and prospect”. Academy of Management Journal, 39: 779-801. ; Murphy, Kevin M. \& Tamura, Robert. (1994), "Human capital, fertility, and economic growth". In: BECKER, Gary S. (ed.). Human capital: a theoretical and empirical analysis with special reference to education. 3rd edition. Chicago, The University of Chicago Press, pp. 323-350.

\& Tomes, Nigel. (1986), "Human capital and the rise and fall of families". Journal of Labor Economics, 4: 1-39.

Benhabib, Jess \& Spiegel, Mark M. (1994), “The role of human capital in economic development: evidence from aggregate cross-country data". Journal of Monetary Economics, 34: 143-173.

BERger, Johannes. (2004), "Über den Ursprung der Ungleichheit unter den Menschen”. Zeitschrift für Soziologie, 33: 354-374.

BERrILl, Kenneth (ed.). (1964), Economic development with special reference to East Asia. New York, St Martin's Press.

Blair, Margaret M. \& Wallman, Steven H.M. (2001), Unseen wealth: report of the brookings task force on intangibles. Washington, DC, Brookings Institution.

BlaUg, Mark. ([1965] 1968), “The rate of return on investment in education”. In: (ed.). Economics of education 1. Harmondsworth, Penguin, pp. 215-259.

Blumenstyk, G. (2012), "Universities report \$1.8-billion in earnings on inventions in 2011". Chronicle of Higher Education, ago. Available in http://www.chronicle.com/article/ University-Inventions-Earned/133972.

Boldrin, Michele \& Levine, David K. (2013), “The case against patents”. Journal of Economic Perspectives, 27: 3-22.

\& David K. LeVine (2005), "The economics of ideas and intellectual property". PNAS, 102: $1252-12156$.

Bonaccorsi, Andrea; Calvert, Jane \& Joly, Pierre-Benoit. (2011), "From protecting texts to protecting objects in biotechnology and software: a tale of changes of ontological assumptions in intellectual property protection". Economy and Society, 40: 611-639. 
Boudon, Raymond. (1974), Education, opportunity and social inequality. New York, Wiley.

Boulding, Kenneth E. (1966), "The economics of knowledge and the knowledge of economics". The American Economic Review, 56: 1-13.

Bourdieu, Pierre. (1999), “Scattered remarks”. European Journal of Social Theory, 2: 334-340. . ([1984] 1988), Homo academicus. Oxford, Polity Press.

. ([1983] 1986), “The forms of capital”. In: Richardson, John G. (ed.). Handbook of theory and research for the sociology of education. New York, Greenwood, pp. 241-258.

. ([1971] 1973), "Cultural reproduction and social reproduction". In: BROwn, Richard (ed.). Knowledge, education, and cultural change. London, Tavistock, pp. 71-112.

\& Passeron, Jean-Claude. ([1964] 1979), The Inheritors: French students and their relation to culture. Chicago, University of Chicago Press.

Boyle, James. (2003), “The second enclosure movement and the construction of the public domain". Law and Contemporary Problems, 66: 33-74.

Bresson, Christian de \& Amesse, Ferdinand. (1991), "Networks of innovators: a review and introduction to the issue". Research Policy, 20: 363-379.

Bryan, Dick; RafFerty, Michael \& Wigan, Duncan. (2017), “Capital unchained: finance, intangible assets and the double life of capital in the offshore world". Review of International Political Economy, 24: 56-86.

Budish, Eric; Roin, Benjamin N. \& HeIdi, Williams. (2016), "Patents and research investments: Assessing the empirical evidence”. NBER Working Paper, 21889. Available in http:// www.nber.org/papers/w21889.

CalHoun, Craig. (1995), Critical social theory: culture, history, and the challenge of difference. Oxford, Blackwell.

Callon, Michel. (1992), “The dynamics of techno-economic networks". In: Coombs, Rod; Saviotti, Paolo \& Walsh, Vivien (eds.). Technological change and company strategies. London, Academic Press, pp. 132-161.

CAPpelli, Peter. (2014), "Skill gaps, skill shortages and skill mismatches: evidence for the us”. NBER Working Paper, 20382. Available in http://www.nber.org/papers/w20382.

Coleman, James S. (1988), "Social capital in the creation of human capital". American Journal of Sociology, 94: 95-120.

Collins, Randall. (1971), "Functional and conflict theories of educational stratification". American Sociological Review, 36 (6): 1002-1019.

Corrado, Carol, A., Hulten, Charles R. \& Sichel, Daniel E. (2006), "Intangible capital and economic growth". NBER Working Paper, 11948.

Crampes, Claude \& Langinier, Corinne. (2009), "Are intellectual property rights detrimental to innovation?". International Journal of the Economics of Business, 16: 249-268.

Crozier, Michel. ([1963] 1964), The bureaucratic phenomenon. Chicago, University of Chicago Press. 
Czarnitzki, Dirk; Hall, Bronwyn H. \& Oriani, Raffaele (2006), “The market valuation of knowledge assets in us and European firms". The management of Intellectual Property. Cheltenham Glos., Edward Elgar, pp. 111-131.

Damay, Cornelia, Guichard, Nathalie \& Clauzel, Amélie (2014), “Children’s price knowledge". Young Consumers, 15: 167-177.

David, Paul A. (2000), "The digital technology boomerang: new intellectual property rights threaten global 'open science". World Bank Conference Paper.

DEMPSEY, Gillian. (1999), "Revisiting intellectual property policy: information economics for the information age". Prometheus, 17: 33-40.

Dewey, John. ([1916] 2005), Democracy and education. Stilwell, Kansas, Dickson.

Dickson, Peter R. \& SAwyer, Alan G. (1990), “The price knowledge and search of supermarket shoppers”. Journal of Marketing, 54: 42-53.

DiMaggio, Paul. (1997), “Culture and cognition”. Annual Review of Sociology, 23: 263-287.

Dosi, Giovanni. (1996), "The contribution of economic theory to the understanding of a knowledge-based economy”. In: Organisation for Economic Co-Operation and Development (ed.). Employment and growth in the knowledge-based economy. Paris, OECD, pp. 81-92.

Drahos, Peter. (2010), The global governance of knowledge: patent offices and their clients. Cambridge, Cambridge University Press. (2004), “The regulation of public goods". Journal of International Economic Law, 7: 321-339.

Drucker, Peter. (1993a), Post-capitalist society. New York, Harper Business.

Dupré, J. Stefan \& LAKoff, Sanford. (1962), Science and the nation: policy and politics. Englewood Cliffs, NJ, Prentice-Hall.

Eggertsson, Thráinn. (2009) "Knowledge and the theory of institutional change". Journal of Institutional Economics, 5: 137-150.

ELIOT, T. S. Choruses from “The Rock" [1934]. In: The complete poems and plays of T. S. Eliot. London, Faber, 1969, pp. 147-150.

European Commisson, International Monetary Fund, Organisation for Economic Co-operation and Development, United Nations and World Bank. (2009), System of National Accounts 2008. New York, European Commisson, International Monetary Fund, Organisation for Economic Co-operation and Development, United Nations and World Bank.

Farre-Mensa, Joan; Hegde, Deepak \& Ljungevist, Alexander. (2017), "What is a paent worth? Evidence from the U.S. patent 'lottery'”. NBER Working Paper, 23268. Ahttp:// www.nber.org/papers/w23268.

FAUlKNer, Wendy; SENKer, Jacqueline \& VELHO, Lea. (1995), Knowledge frontiers: industrial innovation and public sector research in biotechnology, engineering ceramics, and parallel computing. Oxford, Oxford University Press. 
FeHER, Michel. ([2007] 2009), "Self-appreciation; or, the aspirations of human capital”. Public Culture, 21: 21-41.

Feldstein, Martin S. (2017), "Underestimating the real growth of GDP, personal income and productivity”. NBER Working Paper, 23306. Available in http://www.nber.org/papers/w23306.

Fevre, Ralph; Rees, Gareth \& Gorard, Stephen. (1999), "Some sociological alternatives to human capital theory and their implications for research on postcompulsory education and training". Journal of Education and Work, 12: 117-140.

FINK, Carsten \& Maskus, Keith E. (2005), "Why we study intellectual property rights and what we have learned”. In: Fink, Carsten \& MASKus, Keith E. (eds.). Intellectual property and development: lessons from recent economic research. Washington, DC, The World Bank, pp. 1-15.

Foray, Dominique. (2006), The economics of knowledge. Boston, MIT Press.

. (2000), Intellectual property and innovation in the knowledge-based economy. CemiReport-2005-010.

Fourcade, Marion. (2011), "Cents and sensibility: economic valuation and the nature of nature”. American Journal of Sociology, 116: 1721-1777.

Freeman, Chris. (1991), "Networks of innovators: a synthesis of research issues". Research Policy, 20: 499-514.

Fulmer, Ingrid Smithey \& Ployhart, Robert E. (2014), “'Our most important asset': a multidisciplinary/multilevel review of human capital valuation for research and practice". Journal of Management, 40: 161-192.

Gabe, Todd; Florida, Richard \& Mellander, Charlotta. (2013), "The creative class and the crisis". Cambridge Journal of Regions, Economy and Society, 6: 37-53.

Galbraith, John K. ([1967] 1971), The new industrial state. Boston, Houghton Mifflin.

GANGuli, Prabuddha. (2000), "Intellectual property rights. Imperatives for the knowledge industry". World Patent Information, 22: 167-175.

Garcia-Macia, Daniel; Hsieh, Chan-Tai \& Klenow, Peter J. (2016), “How destructive is innovation?”. NBER Working Paper, 22953.

Garicano, Luis \& Rossi-Hansberg, Esteban. (2015), “Knowledge-based hierarchies: using organizations to understand the economy". Annual Review of Economics, 7: 1-30.

Garmon, Cecile W. (2002), "Intellectual property rights". American Behavioral Scientist, 45: 1145-1158.

Garnham, Nicholas \& Williams, Raymond. (1986), "Pierre Bourdieu and the sociology of culture: an introduction". In: Collins, Richard et al. (eds.). Media, culture and society. London, Sage, pp. 209-223.

Geroski, Paul. (1995), "Markets for technology: knowledge, innovation and appropriability”. In: Stoneman, Paul (ed.). Handbook of the economics of innovation and technological change. Oxford, Blackwell, pp. 90-131. 
Ghosн, Rishab A. (2005), Code: collaborative ownership and the digital economy. Cambridge, Massachusetts, MIT Press.

\& SoETE, Luc. (2006), "Information and intellectual property: the global challenges". Industrial and Corporate Change, 15: 919-935.

Golding, Claudia \& KaTz, Lawrence F. (2008), The race between education and technology. Cambridge, Massachusetts, Harvard University Press.

Gorz, André. ([2003] 2010), The immaterial: knowledge, value and capital. Chicago, University of Chicago Press.

. ([2003] 2004), Wissen, Wert und Kapital. Zur Kritik der Wissensökonomie. Berlin, Rotpunktverlag.

Gossner, Olivier. (2010), "Ability and knowledge”. Games and Economic Behavior, 69: 95-106.

Gouldner, Alvin W. (1979), The future of intellectuals and the rise of the new class. New York, Coninuum.

. (1976), The dialectic of ideology and technology: the origins, grammar and future of ideology. New York, Seabury Press

GranovetTER, Mark. (1985), "Economic action and social structure: the problem of embeddedness". American Journal of Sociology, 91: 481-510.

Greenhalgh, Christine \& Rogers, Mark. (2007), "The value of intellectual property rights to firms and society". Oxford Review of Economic Policy, 23: 541-567.

GRUndmann, Reiner \& STEHR, Nico. (2012), The power of scientific knowledge: from research to public policy. Cambridge, Cambridge University Press.

Haggett, Mark \& Kaplan, Greg. (2015), "How large is the stock component of human capital”. NBER Working Paper, 21238. Available in http://www.nber.org/papers/w21238.

HaLl, John R. (1992), “The capital(s) of cultures: a nonholistic approach to status situations, class, gender, and ethnicity”. In: LAmont, Michèle \& Fournier, Marcel (eds.). Cultivating differences: symbolic boundaries and the making of inequality. Chicago, University of Chicago Press, pp. 257-285.

HALLE, David. (1992), “The audience for abstract art: class, culture and power”. In: LAMONT, Michèle \& Fournier, Marcel (eds.). Cultivating differences: symbolic boundaries and the making of inequality. Chicago, University of Chicago Press, pp. 131-181.

HANusheK, Eric A.; SCHWerdt, Guido \& Wiederhold, Simon. (2015), "Returns to skill around the world: evidence from Piaac". European Economic Review, 73: 103-130.

\& Woessmann, Ludger. (2015), The knowledge capital of nations. Cambridge, Massachusetts, MIT Press.

HARdin, Garrett. (1968), “The tragedy of the commons”. Science, 162: 1243-1248.

HARIson, Elad. (2008), "Intellectual property rights in knowledge-based economy: a new frame-of-analysis”. Economic Innovation New Technology, 17: 377-400.

Harrod, Roy F. (1939), “An essay in dynamic theory”. The Economic Journal, 49: 14-33. 
Herszenhorn, David M. (2006), “School financing case argued before State’s highest court”, New York Times. Available in http://www.nytimes.com/2006/10/11/nyregion/1 lequity. html? ref=nyregion \&mcubz=0.

Hess, Charlotte \& Ostrom, Elinor. (2007), Understanding knowledge as a commons: from theory to practice. Cambridge, Miт Press.

$\&$ _ (2003), "Ideas, artifacts and facilities: Information as a common-pool resource”. Law and Contemporary Problems, 66: 111-148.

Hesse, Carla. (2002), "The rise of intellectual property, 700 B.C. - A.D. 2000: an idea in the balance”. Daedalus, 131 (2): 26-45.

Hilgartner, Stephen. (2002), “Acceptable intellectual property”. Journal of Molecular Biology, 319: 943-946.

Hilmer, Michael J. \& Hilmer, Christiana E. (2012), “On the relationship between student tastes and motivations, higher education decisions, and annual earnings". Economics of Education Review, 31: 66-75.

Homburg, Christian; Koschate-Fischer, Nicole \& Wiegner, Christian M. (2012), "Customer satisfaction and elapsed time since purchase as drivers of price knowledge". Psychology and Marketing, 29 (2): 76-86.

Hoti, Suhejla \& McAleer, Michael. (2006), "Intellectual property litigation activity in the USA”. Journal of Economic Surveys, 20: 715-729.

Hu, Winnie \& PéREz-Peña, Richard. (2011). "Court orders New Jersey to increase aid to schools”. New York Times. Available in http://www.nytimes.com/2011/05/25/nyregion/ new-jersey-is-ordered-to-increase-aid-to-schools.html?mcubz=0.

Hume, David. ([1739] 1961), A treatise of human nature. Garden City, New Jersey, Dolphin Books.

InTERView with André Gorz, "Entsinnlichung des Wissens [The loss of meaning of knowledge]". (August 8, 2003), Die Tageszeitung.

Junor, Sean \& Usher, Alex. (2004/2005), “The price of knowledge”. Policy Options, 61-66.

KaUl, Inge; Grunberg, Isabelle \& STERn, Marc A. (1999), "Introduction”. In: KaUl, Inge; Grunberg, Isabelle \& STERn, Marc A. (eds.), Globalpublic goods. International Co-operation in the 21st Century. New York, Oxford University Press, pp. xix-xxxviii.

Knight, H. Jackson (2013), Patent strategy for researchers and research managers. Third edition. New York, John Wiley.

"KNOWLEDGE is democratic". (1851), Scientific American, 6: 253.

Lamont, Michèle \& Lareau, Annette. (1988), "Cultural capital: Allusions, gaps and glissandos in recent theoretical developments". Sociological Theory, 6: 153-168.

Landes, William M. \& Posner, Richard A. (2003), The economic structure of intellectual property law. Cambridge, Massachusetts, Harvard University Press.

Laroche, Mireille \& Mérette, Marcel. (1999), “On the concept and dimensions of human capital in a knowledge-based economy context”. Canadian Public Policy, 25: 87-100. 
LEADBEATER, Charles. (1999), "New measures for the new economy”. International Symposium on Measuring and Reporting Intellectual Capital. Amsterdam, OECD.

LEPpÄLÄ, Samuli. (2015), "Economic analysis of knowledge: the history of thought and the central themes". Journal of Economic Surveys, 29: 263-286.

Li, Xing; MacGarvie, Megan \& Moser, Petra. (2015), “Dead poet's property: how does copyright influence price?". NBER Working Paper, 21522. Available in www.nber.org/ papers/w21522.

Lim, Lynn L.; Chan, Christopher C. \& Dallimore, Peter. (2010), "Perceptions of human capital measures: from corporate executives and investors". Journal of Business and Psychology, 25: 673-688.

Limoges, Camille. (1993), "Expert knowledge and decision-making in controversy contexts". Public Understanding of Science, 2: 417-426.

Lin, Dajun; LutTer, Randell \& Ruhm, Christopher J. (2016), “Cognitive performance and labor market outcome". NBER Working Paper, 22470. Available in http://www.nber.org/ papers/w22470

Lindahl, Mikael, Palme, Mårten, Sandgren-Massin, Sofia \& Sjögren, Anna. (2014), “A test of the Becker-Tomes model of human capital transmission using microdata on four generations". Journal of Human Capital, 8: 80-96.

Link, Albert \& Ruhm, Christopher. (2009), "Public knowledge, private knowledge: the intellectual capital of entrepreneurs". NBER Working Paper, 14797. Available in http://www. nber.org/papers/w14797.

Lipset, Seymour M. (1959), “Some social requisites of democracy: economic development and political legitimacy". American Political Science Review, 53: 69-105.

Long, Clarisa. (2002), "Patent signals”. University of Chicago Law Review, 69: 625-679.

Long, Pamela O. (1991), “Invention, authorship, 'intellectual property', and the origin of patents: Notes toward a conceptual history". Technology and Culture, 32: 846-884.

Luscombe, Mark A. (1996), “Taxation of knowledge”. Taxes, 74: 183.

Maskus, Keith E. \& Reichman, Jerome H. (2004), “The globalization of private knowledge goods and the privatization of global public goods". Journal of International Economic Law, 7:279-320.

MatTHEWs, Duncan. (2011), Intellectual property, human rights and development: the role of NGOs and social movements. Cheltenham, Edward Elgar.

Matthijs, Gert. (2004), "Patenting genes: may slow down innovation, and delay availability of cheaper genetic tests". British Medical Journal, 329: 1358.

McCulla, S.; Holden, A. \& SMith, S. (2013), Improved estimates of national income and product accounts: results of the 2013 comprehensive revision. Washington, DC, Bureau of Economic Analysis.

McGrattan, Ellen R. (2017) “Intangible capital and measured productivity”. NBER Working Paper, 23233. Available in http://www.nber.org/papers/w23233. 
Menger, Carl. ([1871] 1981), Principles of economics. New York, New York University Press. Michels, Robert ([1908] 1987), "Die oligarchischen Tendenzen der Gesellschaft. Ein Beitrag zum Problem der Demokratie”. In: Michels, Robert (ed.). Masse, Führer, Intellektuelle. Frankfurt am Main, Campus, pp. 133-181.

Miller, Jon D. (1983), The American people and science policy. New York, Pergamon.

Mincer, Jacob (1974), Schooling, experience, and earnings. New York, Nber Press.

Mokyr, Joel. (2005), “The intellectual origins of modern economic growth”. Journal of Economic History, 65: 285-351.

\& Voтн, Hans-Joachim. (2009), “Understanding growth in Europe, 1700-1870: theory and evidence: volume 1, 1700-1870”. In: BroAdberry, S. \& O'Rourke, K. H. (eds.), The Cambridge economic history of modern Europe: volume 1, 1700-1870. Cambridge, Cambridge University Press.

Nelkin, Dorothy. (1987), "Controversies and the authority of science". In: ENGLEHARdT, H. Tristam \& Caplan, Arthur L. (eds.). Scientific controversies. Cambridge, Cambridge University Press, pp. 283-294.

. (1975), "The political impact of technical expertise”. Social Studies of Science, 5: 35-54.

Nelson, Benjamin. (1973), "Civilizational complexes and intercivilizational encounters". Sociological Analysis, 34: 79-105.

Nordhaus, Wilhelm D. (1969), Invention, growth and welfare: a theoretical treatment of technological change. Cambridge, Massachusetts, MIT Press.

OECD. (2006), Intellectual assets and value creation: implications for corporate reporting. Paris, OECD.

Olavarrieta, Sergio; Hidalgo, Pedro; Manzur, Enrique \& Farias, Pablo. (2012), "Determinants of in-store price knowledge for packaged products: an empirical study in a Chilean hypermarket”. Journal of Business Research, 65: 1759-1766.

Pakes, Ariel \& Schankerman, Mark. (1979), “The rate of obsolescence of knowledge, research gestation lags, and the private rate of return to the research resources". NBER Working Paper, 346.

Parsons, Talcott ([1949] 1954), "Social classes and class conflict in the light of recent sociological theory”. In: Talcott Parsons (ed.), Essays in sociological theory. New York, Free Press, pp. 323-335.

PiketTy, Thomas. ([2013] 2014), Capital in the Twentieth-First Century. Cambridge, Massachusetts, Harvard University Press.

Pleijt, Alexandra M. de. (2016), "Human capital formation in the long run: evidence from average years of schooling in England, 1300-1900". Cliometrica, 1-28.

PopItz, Heinrich. (1986), Phänomene der Macht: Autorität - Herrschaft - Gewalt - Technik. Tübingen, J.C.B. Mohr (Paul Siebeck).

Przeworski, Adam; Alvarez, Michael; Cheibub, José A. \& Limongi, Fernando. (2000), 
Democracy and development:political institutions and material well-being in the world, 19501990. New York, Cambridge University Press.

ReIss, Roland. (2015), "Eine Kriegserklärung an das Buch” [A declaration of war on books]. Frankfurter Allgemeine Zeitung.

RESNIK, David B. (2004), Owning the genome: a moral analysis of DNA patenting. Albany, New York, State University Press of New York.

Rimes, Hearther; Welch, Jennie \& Bozeman, Barry. (2014), "An alternative to the economic value of knowledge". In: Antonelli, Cristiano \& Link, Albert N. (eds.). Routledge handbook of the economics of knowledge. New York, Routledge, pp. 154-164.

Robinson, Joan. (1979), The generalisation of the general theory and other essays. London, Macmillan.

Rosen, Sherwin. (1975), “Measuring the obsolescence of knowledge”. In: Juster, F. T. (ed.). Education, income and human behavior. New York, Carnegie Foundation for the Advancement of Teaching \& National Bureau of Economic Research, pp. 199-232.

Rosewall, Bridget. (2005), “The knowledge of price and the price of knowledge”. Futures, 37: 699-710.

SCHEFOLD, Bertram. (2010), "Die Ökonomisierung der Wissenskultur [The economisation of the culture of knowledge]". Frankfurter Allgemeine Zeitung, April.

Scherer, Bonnie A. (2004-2005), "Footing the bill for a sound education in New York City: the implementation of campaign for fiscal equity v. state". Fordham Urban Law Journal, 32: 901-935.

Schoellman, Tod. (2012), "Education quality and development accounting". Review of Economic Studies, 79: 388-417.

Schultz, Theodor W. (1992), "Reflections on investment in man".Journal of Political Economy, 70: $1-8$

. (1961), "Investment in human capital". American Economic Review, 51: 1-17.

Schwartz, Jacob T. (1992), “America’s economic-technological agenda for the 1990s". Daedalus, 121: 139-165.

Shaffer, Harry G. (1961), "Investment in human capital: Comment”. American Economic Review, 52: 1026-1035.

Shapin, Steven. (2001), "Proverbial economies how an understanding of some linguistic and social features of common sense can throw light on more prestigious bodies of knowledge, science for example". Social Studies of Science, 31: 731-769.

Simkovic, Michael. (2015), “The knowledge tax”. The University of Chicago Law Review, 82: $1981-2043$

Simmel, Georg. ([1907] 1989), Philosophie des Geldes. Gesamtausgabe Band 6, Frankfurt am Main, Suhrkamp. . ([1907] 1978), The philosophy of money. London, Routledge and Kegan Paul. 
Simon, H. (1999), “The many shapes of knowledge”. Revue d'Economie Industrielle, 88: 23-39. Sollosy, Marc; McInerney, Marjorie \& Braun, Charles K. (2016), "Human capital: a strategic asset whose time has come to be recognized on organizations' financial statements". Corporate Accounting \& Finance, 27: 19-27.

Seuicciarini, Mara P. \& Vogtlaender, Nico. (2014), "Human capital and industrialization: wvidence from the age of enlightenment". NBER Working Paper, 20219. Available in http://www.nber.org/papers/w20219.

STARBUCK, William H. (1992), "Learning by knowledge-intensive firms". Journal of Management Studies, 29: 713-740.

STEHR, Nico. (2016), Information, power, and democracy: liberty is a daughter of knowledge. Cambridge, Cambridge University Press.

. (2002), Knowledge and economic conduct: the social foundations of the modern economy. Toronto, University of Toronto Press.

. (2000), “The productivity paradox: ICT's, knowledge and the labour market". In: Mothe, John de la \& PAQUet, Gilles (eds.). Information, innovation and impacts. Norwell, Massachusetts, Kluwer, pp. 255-272.

. (1999), "The future of inequality". Society 36: 54-59.

\& Adolf, Marian. (2015), Ist Wissen Macht? Erkenntnisse über Wissen. Weilerswist, Velbrück.

STIGLER, George J. (1980) "An introduction to privacy in economics and politics". The Journal of Legal Studies, 9: 623-644.

STIGLiTZ, Joseph E. (2015), “The measurement of wealth: Recessions, sustainability and inequality”. NBER Working Paper, 21327. Available in http://www.nber.org/papers/w21327. . (2014), "Intellectual property rights, the pool of knowledge, and innovation". NBER Working Paper, 20014. Available in http://www.nber.org/paers/w20014.

. (2012), The price of inequality. New York, Norton.

. (2010), "Intellectual property, dissemination of innovation, and sustainable development”. Global Policy, 1: 237-251.

. (1999), “Knowledge as a global public good”. In: KaUL, Inge; GrunberG, Isabelle \& STERn, Marc A. (eds.). Global public goods. International Co-operation in the $21^{\text {st }}$ Century. New York, Oxford University Press, pp. 308-325.

. (1995), "The theory of international public goods and the architecture of international organizations". United Nations Background Paper 7. New York, United Nations.

. \& GREENWALD, Bruce G. (2014), Creating a learning society: a new approach to growth, development, and social progress. New York, Columbia University Press.

Storper, Michael. (1996), "Institutions of the knowledge-based economy". In: oecD (ed.), Employment and Growth in the Knowledge-Based Economy. Paris, OECD, pp. 255-283.

Strathern, Marilyn. (2005), “Imagined collectivities and multiple ownership”. In: GHosh, 
Rishab A. (ed.). Code: collaborative ownership and the digital economy. Cambridge, Massachusetts, MIT Press, pp. 13-28.

SwaIns, Howard. (2015), "Free football streaming: how illegal sites keep outpacing broadcasters". The Guardian. Available in http://www.theguardian.com/football/2015/aug/01/ faster-easier-free-illegal-football-streams, accessed August 1, 2015.

Sweney, Mark. (2012), "Pub landlady Karen Murphy wins Premier League Tv battle”. Available in http://www.theguardian.com/media/2012/feb/24/pub-landlady-karen-murphypremier-league, accessed August 1, 2015.

TAN, Emrullah. (2014), "Human capital theory: a holistic criticism". Review of Educational Research, 84: 411-445.

TEAL, Francis. (2011), "The price of labour and understanding the causes of poverty". Labour Econnomics, 18: 7-15.

Teece, David J. (1998), “Capturing value from knowledge assets: the new economy, markets for know-how, and intangible assets". California Management Review, 40: 55-79.

UNU-IHDP \& Unep. (2014), Inclusive wealth report 2014: measuring progress toward sustainability. Cambridge, Cambridge University Press.

VAn Doorn, Niels. (2014), “The neoliberal subject of value: Measuring human capital in information economies”. Cultural Politics, 10: 354-375.

VAN DEN DAele, Wolfgang. (1996), “Objektives Wissen als politische Ressource: Experten und Gegenexperten im Diskurs". In: \& NeIDHARDT, Friedhelm (eds.). Kommunikation und Entscheidung. Berlin, Sigma, pp. 297-326.

VAN Eekelen, Bergie F. (2015), “Accounting for ideas: bringing a knowledge economy into the picture". Economy and Society, 44: 445-479.

Vazquez, Alfredo Macias \& Gonzalez, Pablo Alonso. (2016), "Knowledge economy and the commons: a theoretical and political approach to postneoliberal common governance". Review of Radical Political Economy, 48: 140-157.

Veblen, Thorstein. ([1908] 1919), “The nature of capital”. In: Veblen, Thorstein (ed.). The place of science in modern civilisation and other essays. New York, The Viking Press, pp. 324-386.

WACQuant, Loic D. (1989), "Towards a reflexive sociology: a workshop with Pierre Bourdieu”. Sociological Theory, 7: 26-63.

Welch, Finis \& URETA, Manuelita. (2002), “The obsolescence of skill”. Labor Economics, 21: 51-81. Available in https://doi.org/10.1016/S0147-9121(02)21005-5.

Williams, Heidi L. (2016), "Intellectual property rights and innovation: evidence from health care markets". Innovation Policy and the Economy, 16: 53-87.

Williamson, Oliver E. (1975), Market and hierarchies: analysis and antitrust implications. New York, The Free Press.

WORLD BANK. (2011), The changing wealth of nations: measuring sustainable development in the new millennium. Washington, DC, World Bank. 
Worth, Robert F. \& Hartocollis, Anemona (2002), "Johnny can read, not well enough to vote?”. New York Times. Available in http://www.nytimes.com/learning/teachers/featured_articles $/ 20020701 \mathrm{monday} \cdot \mathrm{html}$ ? mcubz=0.

Zhou, Yi. (2015), “The tragedy of the anticommons in knowledge”. Review of Radical Political Economics, 28: 158-175.

\section{Abstract}

\section{The price of knowledge}

This article addresses the apparently rather old question as the citation from the 1851 issue of the Scientific American indicates - of how to assess and measure the value or price of knowledge. We will probe the issue from a variety of social scientific and practical perspectives. Against the background of a sociological concept of knowledge economic, political, social and juridical perspectives are discussed that may lead us to a price of knowledge.

Keywords: Value of knowledge; Patents; Intangibles; Public goods; Price of knowledge; Human capital; Modern economy.

\section{Resumo}

\section{O preço do conhecimento}

O artigo aborda uma questão aparentemente antiga, como sugere a citação inicial tomada à edição de 1891 da revista Scientific American, de como avaliar e medir o valor ou o preço do conhecimento. A questão será estudada de várias perspectivas, tanto da prática como das ciências sociais. Tomando por base um conceito sociológico de conhecimento, discutiremos as perspectivas econômica, social, política e jurídica que podem nos conduzir à noção de preço do conhecimento. Palavras-chave: Valor do conhecimento; Patentes; Intangíveis; Bens públicos; Preço do conhecimento; Capital humano; Economia moderna.

Texto recebido em 5/9/2017 e aprovado em 24/9/2017. DOI: 10.11606/0103-2070. ts.2018.137735.

NICO STEHR is Karl-Mannheim Chair of Cultural Studies at Zeppelin University, Germany. E-mail: nico.stehr@t-online.de.

MARIAN ADOLF is professor of Media Cultura at Zeppelin University, Germany. E-mail: marian. adolf@zu.de. 